Staff Working Paper/Document de travail du personnel 2017-9

\title{
Expropriation Risk and FDI in Developing Countries: Does Return of Capital Dominate Return on Capital?
}

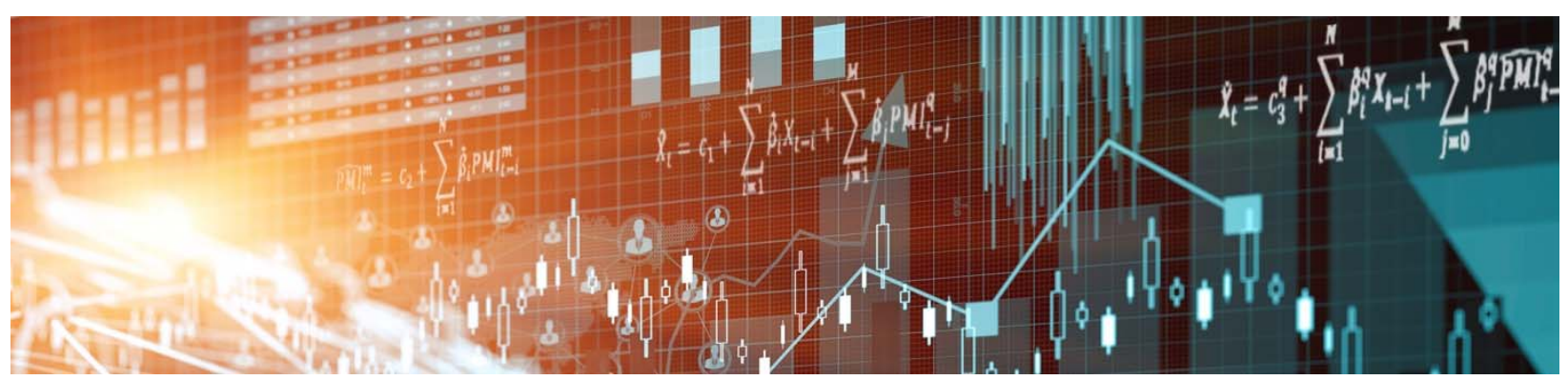

by M. Akhtaruzzaman, Nathan Berg and Christopher Hajzler 
Bank of Canada Staff Working Paper 2017-9

February 2017

\section{Expropriation Risk and FDI in Developing Countries: Does Return of Capital Dominate Return on Capital?}

by

M. Akhtaruzzaman, ${ }^{1}$ Nathan Berg ${ }^{2}$ and Christopher Hajzler ${ }^{3}$

1Toi Ohomai Institute of Technology, New Zealand

and

Department of Economics

Shahjalal University of Science and Technology, Bangladesh

akhtar.zaman@toiohomai.ac.nz

2Department of Economics

University of Otago, New Zealand

and

Department of Economics

University of Newcastle, Australia

nathan.berg@otago.ac.nz

IInternational Economic Analysis Department

Bank of Canada

Ottawa, Ontario, Canada K1A 0G9

and

Centre for Applied Macroeconomic Analysis, Australia

chajzler@bankofcanada.ca 


\section{Acknowledgements}

The authors are grateful for helpful comments and suggestions from Dorian Owen, Murat Genc, Jonathan Rosborough and Oleksiy Kryvtsov. We also thank participants of the International Conference of the Restructuring of the Global Economy at Oxford and the UAE Quantitative Research Symposium at Zayed University, as well as seminar participants at Bank of Canada, the Bank of England and the University of Otago, New Zealand, for useful discussions. The views expressed in this paper are those of the authors, and do not necessarily reflect the views of the Bank of Canada or its Governing Council. All remaining errors are the responsibility of the authors. 


\begin{abstract}
Previously reported effects of institutional quality and political risks on foreign direct investment (FDI) are mixed and, therefore, difficult to interpret. We present empirical evidence suggesting a relatively clear, statistically robust, and intuitive characterization. Institutional factors that affect the likelihood of an abrupt and total loss of foreigners' capital (i.e., return of capital) dominate those that affect rates of return conditional on a strictly positive terminal investment value (i.e., return on capital). A one-standarddeviation reduction in expropriation risk is associated with a 72 per cent increase in FDI, which is substantially larger than the effects of any other dimensions of institutional quality simultaneously controlled for in our empirical models of FDI inflows. This evidence is consistent with the predictions of a standard theory of FDI under imperfect contract enforcement. We show in the context of a simple model with endogenous expropriation that, when there is a binding threat of expropriation, foreign investors can become unresponsive to differences in other dimensions of institutions and political risk, and may even reduce optimal investment as these institutions improve.
\end{abstract}

Bank topics: Development economics, International financial markets JEL codes: D23, F21, F23

\title{
Résumé
}

Les effets signalés antérieurement qu'exercent la qualité des institutions et les risques politiques sur l'investissement direct étranger (IDE) sont contrastés et, par conséquent, difficiles à interpréter. Nous présentons des données empiriques qui font ressortir une caractérisation intuitive statistiquement solide. Les facteurs institutionnels ayant une incidence sur la probabilité d'une perte soudaine et totale du capital détenu par des étrangers (remboursement de capital) l'emportent sur ceux touchant les taux de rendement subordonnés à une valeur nue finale strictement positive (rendement du capital investi). Une réduction de un écart-type du risque d'expropriation est associée à une augmentation de $72 \%$ de l'IDE, une hausse nettement supérieure à celles engendrées par n'importe quels autres aspects de la qualité des institutions pris en compte simultanément dans nos modèles empiriques d'entrées d'IDE. Ce résultat cadre avec les prédictions d'une théorie classique de l'IDE où l'exécution des contrats est imparfaite. Dans un modèle simple intégrant un facteur d'expropriation endogène, nous démontrons que, en cas de menace d'expropriation à caractère exécutoire, les investisseurs étrangers peuvent devenir indifférents aux divergences entre les autres aspects des institutions et du risque politique, et qu'ils pourraient même réduire l'investissement optimal à mesure que ces institutions s'améliorent.

Sujets : Économie du développement; Marchés financiers internationaux

Codes JEL : D23, F21, F23 


\section{Non-Technical Summary}

How important is expropriation risk relative to other dimensions of institutional quality in accounting for observed patterns of foreign direct investment (FDI) to developing countries and emerging markets? Recent data show that the frequency of expropriations of FDI has increased since the early 1990s, and therefore contracts between privately owned multinationals and sovereign nations remain difficult to enforce. This recent wave of foreign asset seizures suggests that protection of property rights is likely to be a growing concern among foreign investors when deciding where to invest.

Previously reported effects of institutional quality and political risks on FDI are mixed and, therefore, difficult to interpret. There is strong empirical evidence that weak host-country institutions, broadly defined, are associated with lower FDI inflows. However, there is considerable disagreement as to whether weak contract enforcement or a number of other dimensions of political and legal institutions matter most for explaining this relationship between institutional quality and FDI.

Building on previously published panel-data analysis, we revisit the question of which among multiple dimensions of institutional quality help explain FDI inflows to developing and emerging markets. We estimate econometric models expressing FDI inflows as a conditional function of macroeconomic and detailed measures of political risk and institutions for 83 developing economies over the period 19842011. Our model specifications are chosen to address several econometric challenges. We demonstrate that different model specifications produce predictable inconsistencies that likely contribute to disagreement in the empirical literature, particularly those concerning the relative importance of expropriation risk on FDI.

We find that institutions that affect the likelihood of an abrupt and total loss of foreigners' capital (i.e., return of capital) dominate factors that affect rates of return conditional on strictly positive terminal investment value (i.e., return on capital). In particular, a one-standard-deviation reduction in expropriation risk is associated with a 72 per cent increase in FDI inflows on average, which is substantially larger than the effects of other dimensions of institutional quality. Most other measures of institutional quality we consider have no significant effects on FDI once the relative strength of a country's contract enforcement is accounted for.

We show that this evidence is consistent with a simple model of FDI featuring endogenous expropriation and other political risk factors that influence the mean and volatility of foreign asset returns. In this environment, weak enforcement of FDI contracts, which raises the host country's temptation to expropriate, unambiguously reduces the incentive to invest. When risk of expropriation is high, however, FDI no longer responds positively to improvements in other dimensions of institutional quality (and, counterintuitively, may even decrease with improvements in the quality of some institutions). 


\section{Introduction}

A potentially important barrier to foreign investment in many countries is the risk of expropriation. Recent data suggest that, despite global efforts to strengthen foreign investor dispute settlement through trade and investment treaties, contracts between privately owned multinationals and sovereign nations remain difficult to enforce. ${ }^{1}$ Figure 1 shows the frequency of expropriations of foreign direct investment (FDI) in recent decades, which have increased since the early 1990s. ${ }^{2}$ Although a relatively large share of these expropriations are in mining and petroleum (which account for 44 per cent of all incidents from 1990-2014), expropriations have also become more common in other sectors, particularly in utilities and telecommunications, and are geographically widespread. ${ }^{3}$ This recent wave of foreign asset seizures suggests that protection of property rights is likely to be a growing concern among foreign investors when deciding where to invest.

An extensive theoretical literature on foreign investment with imperfect contract enforcement has examined conditions under which opportunistic governments seize foreign assets, and how this risk distorts foreign investment decisions and host-country welfare. ${ }^{4}$ Empirical evidence concerning the specific question of whether expropriation risk reduces FDI inflows to developing and emerging markets is, however, surprisingly mixed. There is strong empirical evidence that weak host-country institutions, broadly defined, are associated with lower FDI inflows. ${ }^{5}$ There is far less consensus on which among a

\footnotetext{
${ }^{1}$ Global bilateral investment treaties (BITs) have increased tenfold over 1990-2009, and there is evidence that they have been somewhat effective in encouraging FDI in industries where, owing to large sunk costs, investors are more vulnerable to expropriation (see Colen et al., 2016). The rise in BITs has also coincided with increasing use of investor-state dispute settlement (ISDS) mechanisms, particularly against executive branches of government (Caddel and Jensen, 2014). However, owing to their increasing legal complexity and the associated risks to the host country, many governments have recently moved away from reliance on ISDS clauses in BITs (Karl, 2013).

${ }^{2}$ These data are described in detail in Hajzler and Rosborough (2016). Expropriation is defined narrowly as a forced transfer of foreign-owned investment assets involving any number of firms within a given industry and excludes less overt contract changes - often referred to as "creeping expropriation"- that could influence the value of foreign-owned assets without involving transfer of ownership. Kobrin (1984) discusses advantages of this measure.

${ }^{3}$ The surge in commodity prices over this period helps explain the increased temptation of host-country governments to nationalize foreign assets in natural resources (Guriev et al., 2011; Hajzler, 2012; Stroebel and Van Benthem, 2013). However, the large number of incidents in non-extractive sectors suggests expropriation risk is far-reaching.

${ }^{4}$ The theoretical contributions discussed in Section 4 establish implications not only for aggregate FDI dynamics, but also multinationals' choice of technology, the structure of natural resource contracts, the optimal mix of foreign equity and debt financing, and aggregate growth and volatility.

${ }_{5}^{5}$ See Alfaro et al. (2008); Faria and Mauro (2009); Papaioannou (2009); Okada (2013); Reinhardt et al. (2013). Using the institutional quality index published by the PRS Group's International Country Risk
} 


\section{Figure 1: Number of Expropriation Acts in All Developing Countries}

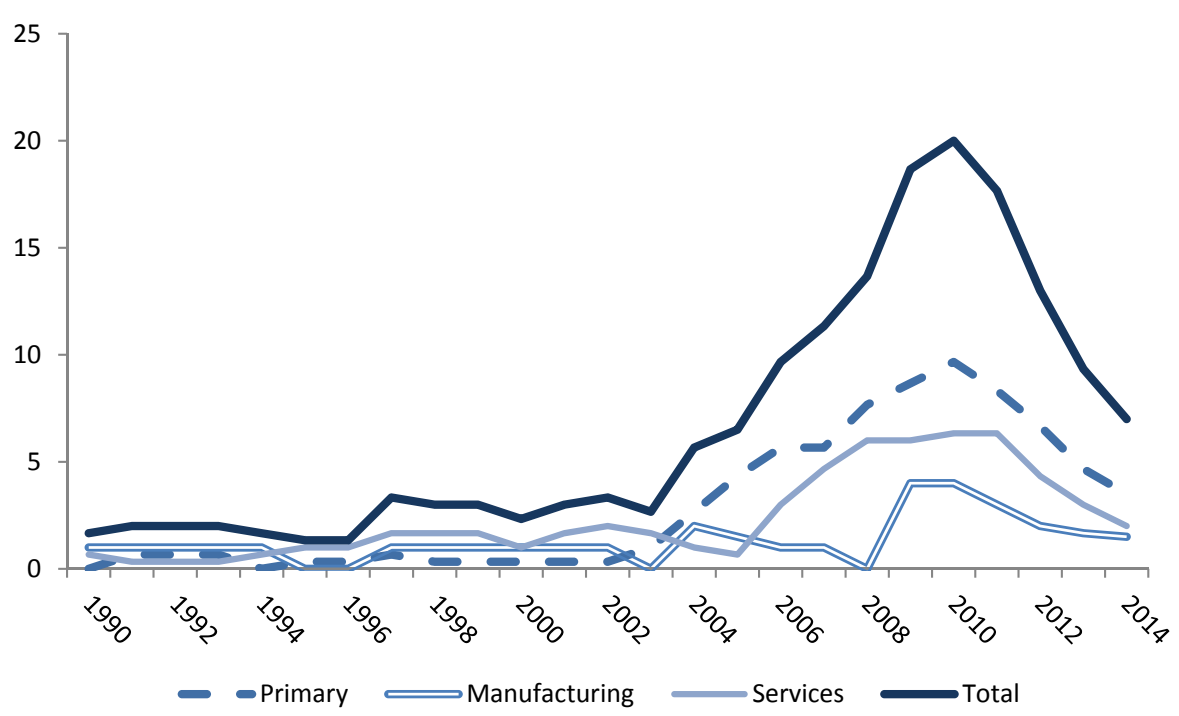

Source: Hajzler and Rosborough (2016).

target country's multiple legal and political institutions matter most to foreign investors. Some authors find that contract enforcement (or property rights relating to expropriation risk) is an important channel through which institutional quality influences foreign capital flows (e.g., Gastanaga et al., 1998; Ali et al., 2010; Asiedu et al., 2009; Asiedu and Lien, 2011; Daude and Stein, 2007; Harms and Ursprung, 2002; Li and Resnick, 2003). Other empirical investigations, however, find no (or weak) evidence linking the strength of contract enforcement to FDI (see, for example, Asiedu, 2002; Bénassy-Quéré et al., 2007; Busse and Hefeker, 2007; Jensen, 2003; Naudé and Krugell, 2007; Sánchez-Martin et al., 2014). ${ }^{6}$ The latter body of work finds that measures of institutional quality (alternatively referred to as "political risk variables") other than expropriation risk-such as corruption, regulatory burden, and democratic accountability in establishing laws-are more important determinants of FDI inflows.

In this paper, we revisit the question of which among multiple dimensions of institutional quality matter most in explaining FDI inflows to developing and emerging markets. Building on previously published panel-data analysis, we estimate econometric

Guide (ICRG), Alfaro et al. (2008) find that institutions may even fully account for Lucas's (1990) paradoxical finding that capital tends to flow "uphill" from capital-poor to capital-rich countries.

${ }^{6}$ Some papers cited above report a negative empirical relationship between expropriation risk and FDI. These findings are, however, rather sensitive to which countries and time periods are included in the sample and whether per capita income is included as a control. 
models expressing FDI inflows as a conditional function of macroeconomic and multiple institutional variables for 83 developing economies over the period 1984-2015. The model specifications are chosen to address several econometric challenges that plausibly contribute to disagreement in the empirical literature. Choice of dependent variable (net versus gross FDI inflows), whether potentially correlated measures of institutional quality are simultaneously controlled for, whether the estimators account for unobserved heterogeneity, and inclusion of key control variables in the conditional mean function are each shown to have important influence on measured effects of expropriation risk on FDI inflows. We pay particular attention to the benefits of specifications that include an expansive set of variables measuring multiple dimensions of institutional quality (to deal with misspecification bias) relative to their cost (less precise estimates due to multicollinearity and the greater informational demands on available data from larger numbers of parameter estimates).

Our empirical results point clearly toward expropriation risk-the risk that an FDI investor abruptly loses 100 per cent of invested principal—as having a much larger impact on FDI than other dimensions of institutional quality commonly considered in the empirical FDI literature. This evidence is robust across a rather wide range of alternative model specifications. The data on institutional quality data used in our analysis are based on 12 indices capturing country-specific political risks, which include a measure of the strength of contract enforcement for foreign investors. ${ }^{7}$ We first consider models based on the most fine-grained categorization of institutional quality captured by all 12 political risk indices. We follow with empirical model specifications that use a coarser set of five semi-aggregated composite indicators of institutional quality in order to mitigate potential measurement error and multicolinearity. ${ }^{8}$ Across all model specifications and taxonomies of composite institutional quality that we consider, the estimated elasticity of FDI with respect to expropriation risk is large compared with all other categories of political risk. Likewise, comparing the effects of standardized improvements in each institutional quality measure on FDI suggests that expropriation risk is a higher-order

\footnotetext{
${ }^{7}$ These data are from the PRS Group's International Country Risk Guide (ICRG), and are described in detail in Section 2.3.

${ }^{8}$ For discussion of the econometric challenges associated with simultaneously controlling for large numbers of institutional quality measures, see Biswas (2002); Busse and Hefeker (2007); Gastanaga et al. (1998); Kolstad and Villanger (2008); and Ali et al. (2010). By averaging out some of the redundant information across the disaggregated indexes, estimation precision can be improved without omitting any set of observable dimensions of institutional quality as several earlier papers have done, which can result in model misspecification.
} 
concern among foreign investors. ${ }^{9}$

Finally, we provide a theoretical interpretation for why we find little evidence for the positive influence of various aspects of host-country institutional quality on FDI once the effects of expropriation risk are accounted for. We present a simple model of FDI in which the host-country government makes an optimal expropriation decision, and which includes other political risk factors that influence the mean and volatility of foreign asset returns (conditional on no expropriation). In this environment, weak enforcement of FDI contracts unambiguously reduces the incentive to invest. When risk of expropriation is high, however, we show that FDI no longer responds positively to improvements in other dimensions of institutional quality, and may even decrease with institutional quality improvements (holding expropriation risk constant). This suggests that some aspects of institutional quality may have ambiguous effects on FDI whenever perceived risks of expropriation are salient in foreign investors' minds.

If an asset is expropriated, institutions that only affect its mean return and variance are no longer relevant. ${ }^{10}$ In fact, an improvement in institutions along a single nonexpropriation dimension (which raises the value of the asset to the investor relative to the host country) can, counterintuitively, discourage FDI by increasing the host-country government's temptation to expropriate. The old adage in finance (apparently mis-attributed to American entertainer Will Rogers) would seem relevant to choosing the location of an FDI project: "I am not so much concerned with the return on capital as I am with the return of capital."

The rest of the paper is organized as follows. Section 2 describes the data and our econometric models of FDI and political risk, and discusses key methodological challenges in relation to the existing literature. Section 3 presents our empirical results. In Section 4, we present a simple theoretical model of FDI with endogenous expropriation risk and derive several predictions for key relationships between FDI and various dimensions of political risk in line with our empirical estimates. Section 5 discusses the main

\footnotetext{
${ }^{9}$ Specifically, we estimate and compare increases in FDI inflows associated with ceteris paribus improvements in each institutional variable. (i.e., worst-to-best or one-standard-deviation improvements in one index while holding the others at their sample means).

${ }^{10} \mathrm{~A}$ similar argument can be made on the basis of lexicographic decision-making models proposed in behavioral finance insofar as destination countries with sufficiently high expropriation risk may be discarded from consideration, regardless of how attractive expected returns may be (c.f., Gigerenzer and Goldstein, 1996; Berg and Gigerenzer, 2007; Berg, 2014a,b). An interesting avenue for future work would be to adopt a likelihood function approach and explicitly model threshold effects by which non-expropriation-related institutional factors (those that affect expected returns conditional on no expropriation event) influence FDI only when expropriation risk is sufficiently low.
} 
insights from our empirical estimates from the perspectives of both the theory and recent expropriation events. Section 6 concludes.

\section{Quantifying the Effects of Institutions on FDI}

A number of modeling decisions may critically affect one's ability to identify the effects of institutional quality on FDI in the data. These modeling decisions include choice of dependent variable, specification of the conditional mean function, and choice of which indices measuring institutional quality to include. ${ }^{11}$ Estimates in this literature are also often based on reduced-form relationships rather than derived from explicitly stated structural models of FDI. Depending on different specifications of FDI's conditional mean, inconsistent empirical results are therefore to be expected.

\subsection{Net versus Gross FDI}

One challenge in comparing empirical findings is the different dependent variables usedgross FDI inflows versus net FDI flows (the latter defined as inward gross FDI flows minus outward gross FDI flows). ${ }^{12}$ Even when net flows are the primary object of interest, analyzing the effects of institutional quality on each gross directional flow and then combining them (as in Globerman and Shapiro (2002)) has several advantages over using net FDI as the dependent variable, which is more prone to misspecification. Barring the very special case in which gross FDI inflows and reverse outflows (i.e., the negative of gross outflows) respond identically to each of the institutional characteristics of the domestic economy, any attempt at estimating the relationship between domestic institutions and net FDI using a linear (or log-linear) regression model will produce biased estimates. (An example of this bias drawing on the theoretical model of Section 4 is provided in Appendix D.) A more reliable approach, in our view, is to model each of these directional flows with distinct empirical models.

In addition to the econometric advantages of using distinct empirical models for gross inflows and outflows, economic theory also supports analyzing the determinants of gross

\footnotetext{
${ }^{11}$ Our empirical analysis uses the Political Risk Group's ICRG indices measuring 12 dimensions of political risk and five semi-aggregated composites based on those 12 ICRG indices grouped according to criteria explained in Section 2.3.

${ }^{12}$ In empirical models of the impact of institutional quality on FDI, gross inflows appear to be used more often, although net FDI inflows are also used (Asiedu, 2002; Asiedu et al., 2009; Asiedu and Lien, 2011; Busse and Hefeker, 2007; Globerman and Shapiro, 2002; Schneider and Frey, 1985).
} 
inflows - rather than net flows - as a primary dependent variable of interest. Independent of the degree to which a developing country's firms choose to invest in foreign projects, inward FDI is positively associated with further opportunities for economic development because it improves access to intangible knowledge and may bring other positive spillovers. Insofar as this mix of intangible and tangible benefits from gross FDI inflows is the focus of analysis, several authors argue that financial flows may be a poor measure of foreign investor activity owing to measurement error that varies systematically with other host-country characteristics (e.g., Bellak, 1998; Bellak and Leibrecht, 2009; Beugelsdijk et al., 2010; Kerner, 2014; Lipsey, 2007). ${ }^{13}$ Acknowledging these potential limitations, estimating the effects of institutional variation on aggregate, gross FDI inflows allows for straightforward comparisons of our findings with those previously reported and provides more extensive coverage of developing countries than other data sources.

\subsection{Normalization of the Dependent Variable}

Empirical approaches in the exiting literature also differ according to scaling, or normalization, of the dependent variable. Some authors choose to model FDI in levels without rescaling, as in Egger and Winner (2005), Jensen (2003) and Li and Resnick (2003). Others specify the dependent variable as the natural log of FDI (or closely related transformations), as in Busse (2004), Globerman and Shapiro (2002), Habib and Zurawicki (2002), Mathur and Singh (2013) and Yang (2007), as well as the analysis of bilateral flows using gravity models in Bénassy-Quéré et al. (2007), Daude and Stein (2007) and Wei (2000). When estimating the determinants of unscaled aggregate FDI inflows using cross-country data, it is, of course, essential to control for country size by including a measure of aggregate economic activity or population (or both) among the explanatory variables. Even if one controls for country size, however, a key question is whether a oneunit (or percentage-point) increase in the political risk index of interest will have similar

\footnotetext{
${ }^{13}$ Specifically, these authors argue that real multinational activity tends to be overstated by aggregate FDI statistics in countries that act as tax havens for foreign investors (e.g., foreign-owned businesses functioning primarily as destinations for parent holding companies' financial flows but whose financial capital exceeds productive investment). Real multinational activity is similarly understated in countries with higher labor productivity (which magnifies the return from each dollar invested) and more developed domestic financial markets (which afford multinationals greater opportunities to partially finance their FDI projects with domestic sources of external capital that do not show up in balance of payments statistics). FDI data can also be misleading if foreign subsidiaries are owned by several parent companies, each with equity shares of less than 10 per cent (Bellak, 1998) or when multinationals rely heavily on transfer pricing, which inflates debt values (and hence reinvested earnings) on affiliate balance sheets (Bellak and Leibrecht, 2009).
} 
effects on the dollar value of FDI inflows across countries regardless of size, or whether these dollar effects should be proportional to market size, and the magnitude of FDI. We adopt a log-linear specification motivated by the view that changes in a country's profile of institutional quality should be associated with proportional changes in gross FDI inflows (measured as expected change in log-approximated percentage points).

An additional consideration is whether to normalize the dependent variable by either national income or population size. National income normalization is adopted in much of the empirical FDI literature, where the dependent variable is either net or gross FDI expressed as a share of gross domestic product (GDP) or gross national income (GNI) (e.g., Ali et al., 2010; Addison and Heshmati, 2003; Asiedu, 2002, 2006; Asiedu et al., 2009; Asiedu and Lien, 2011; Adam and Filippaios, 2007; Gastanaga et al., 1998; Méon and Sekkat, 2004; Naudé and Krugell, 2007; Noorbakhsh et al., 2001; Sánchez-Martin et al., 2014). Other empirical FDI studies, however, normalize by country-year-specific population and use FDI (net or gross) per capita as the dependent variable (e.g., Chakrabarti, 2001; Harms and Ursprung, 2002; Kinoshita and Campos, 2003; Schneider and Frey, 1985).

Whether to normalize FDI by aggregate economic activity or population should depend on the theoretical mechanisms and questions of primary interest. When estimating effects of institutional quality on FDI, we note that it may be particularly difficult to identify their relative importance when FDI is expressed as a share of GDP if institutional quality is also directly related to GDP (Kolstad and Tøndel, 2002; Harms, 2002). For this reason, we choose log FDI per capita as the appropriate dependent variable for our analysis. ${ }^{14}$

Log-transforming the dependent variable (whether normalized by population or market size) enjoys support based on both theoretical arguments and the statistical properties of the data. For example, Kolstad and Tøndel (2002) and Harms and Ursprung (2002) use log FDI per capita as their dependent variable, while Méon and Sekkat (2004) use log of FDI as a share of GDP. Busse and Hefeker (2007) examine log of net FDI per worker as their dependent variable. One important consideration when log-transforming the dependent variable is how to deal with non-positive values of FDI, a problem similar to that encountered with zero-valued trade flows in gravity models (e.g., Linders and de Groot,

\footnotetext{
${ }^{14}$ Globerman and Shapiro (2002) consider the ratio of FDI to GDP as the dependent variable in their study but reject this specification because the dependent variable is typically clustered within a narrow range of variation, which produces unreliable parameter estimates with little explanatory power.
} 
2014; Helpman et al., 2008). Aggregate gross inflows can sometimes be negative due to disinvestment and repatriation of affiliate profits, though negative aggregate gross flows are observed infrequently. Net inflows, on the other hand, are much more commonly negative. Rather than simply dropping negative observations from the sample, Busse and Hefeker (2007) and Globerman and Shapiro (2002) apply different transformations to the dependent variable. We follow Busse and Hefeker (2007) in applying the inverse hyperbolic sign (IHS) transformation to deal with the handful of negative gross FDI inflows in our data set without discarding observations. This transformation approximates the log function for large positive values of the dependent variable and becomes nearly linear for small positive and negative values (see Appendix D, Equation (D.3), for details). In contrast to other normalizations and transformations, our dependent variable using the inverse hyperbolic sign transformation has a remarkably symmetric empirical distribution.

\subsection{Indices Measuring Institutional Quality and Political Risks}

Different data sources and measures of institutional quality appear in the literature. These include indices of expropriation risk, political instability, government corruption, socioeconomic and ethnic tensions, military conflict and democratic accountability, among others. Among numerous data sources for measuring the multiple dimensions of institutional quality and estimating their effects on FDI, we use the PRS Group's International Country Risk Guide (ICRG) indices for two primary reasons. First, these indices provide greater detail on several key dimensions of institutional and political risk compared with other data sources. They also enjoy relatively wide coverage of countries and years in comparison with other measures of institutional quality.

The ICRG Investment Profile index captures three sub-categories of risk with regard to foreign investors' property rights: risk of outright expropriation of assets, payment delays, and restrictions on profit repatriation. ${ }^{15}$ Although Investment Profile does not exclusively measure expropriation risk, this index nevertheless provides a strong proxy for it, and we therefore use it as our primary measure of expropriation risk. The ICRG data also enable finer comparisons of the effects of different political risks and greater flexibility when constructing composite risk indicators (discussed below).

A second reason in favor of the ICRG data is that they are widely used in previous

\footnotetext{
${ }^{15} \mathrm{~A}$ description of each of the ICRG indices is available on the PRS website: http://www. prsgroup.com/wp-content/uploads/2012/11/icrgmethodology.pdf.
} 
studies estimating effects of institutional quality on FDI (possibly owing to some of the benefits just mentioned). The ICRG indices therefore enable comparison of our findings with those in the broader literature. (See Appendix A for a summary of related empirical literature on the effects of expropriation risk on FDI, as well as the various political risk measures used.) ${ }^{16}$

The World Bank's Worldwide Governance Indicators (WGI) also include measures for a range of political risks and would therefore be a potential alternative or complement to the ICRG indices. The WGI data, however, are available for a shorter time span and the WGI measure of property rights protection for foreign investors-Rule of Law-is more broadly defined than the ICRG Investment Profile. ${ }^{17}$

Several other data sources have been used in previous empirical analyses of FDI focusing on a particular category of institutional quality or political risk. These specialized measures of political risk have some potential advantages over the ICRG and WGI indices but coverage of other categories of risk is limited. ${ }^{18}$ Given that the objective of this paper is to compare the relative importance of various categories of political risk for FDI decisions, we focus on the ICRG data, which provide detail and breadth as well as consistently constructed risk measures available across a wide range of countries and extensive time span.

The ICRG indices are re-scaled such that each index is measured on a common 010 scale, with larger values corresponding to better institutional quality (i.e., measuring inverse political risk). We estimate the conditional mean of transformed gross FDI as a function of all 12 measures of institutional quality. Although this conditional mean is likely over-specified (with too many right-hand-side variables given the available sample

\footnotetext{
${ }^{16}$ The aggregate ICRG political risk index has also been used in a relatively large number of papers (e.g., Albuquerque, 2003; Alfaro et al., 2008; Okada, 2013; Papaioannou, 2009; Reinhardt et al., 2013), and various ICRG subcomponents have been widely used in examinations of other dimensions of political risk (e.g., Arezki and Brückner, 2011; Hakkala et al., 2008; Li, 2009).

${ }^{17}$ We re-estimated each empirical model reported below using WGI data, which led to no qualitative differences in the main results. Among the six WGI political risk indices, Rule of Law tends to have both the largest and most consistently statistically significant impact on FDI. For brevity, we present findings based on the ICRG data.

${ }^{18}$ For example, Jensen's (2008) and Stroebel and Van Benthem's (2013) measure of expropriation risk, Constraints on the Executive from the Polity IV database, measures the extent of legislated constraints on the decision-making powers of the government executive; fewer constraints are interpreted as a lower cost of expropriation (and therefore higher risk). An advantage of this measure is that it is based entirely on objective categorical indicators (whereas ICRG and WGI ratings both combine subjective evaluations of survey and economic data). A possible disadvantage of this measure, however, is that it could include adverse policy decisions unrelated to expropriation.
} 
sizes), the advantage of simultaneously controlling for all 12 indices is mitigating against misspecification from omitted variables. However, asking the information contained in our sample to estimate such a large number of coefficients may reduce the precision of the coefficient estimates. The challenge of jointly estimating the effects of conceptually overlapping indices of institutional quality is discussed in Gastanaga et al. (1998) and Kolstad and Villanger (2008). Ali et al. (2010) argue that highly disaggregated indices are more prone to measurement error, while Biswas (2002) and Busse and Hefeker (2007) emphasize multicollinearity (among the 12 ICRG indices) as the greater methodological challenge. Some authors deal with the issue of multicollinearity by focusing only on a selective set of institutional variables (e.g., Adam and Filippaios, 2007; Sánchez-Martin et al., 2014) or by presenting estimates from models that include only one political risk variable at a time (Busse and Hefeker, 2007; Bénassy-Quéré et al., 2007; Daude and Stein, 2007; Gastanaga et al., 1998). However, if other related institutions in the FDIdata-generating process are omitted from the model, then estimates will, in general, suffer from bias.

We take an alternative approach to addressing such concerns over multicollinearity by estimating a version of the model that replaces the 12 ICRG indices with a smaller number of semi-aggregated composite indicators - coarsening the fine-grained 12 dimensions of variation in institutional quality to five (specified below). Each composite is an average across a subset of individual indices grouped according to conceptual overlap. Our approach aims to reduce the number of possible dimensions along which conceptually related indices may contain redundant information. ${ }^{19}$ Identifying the appropriate classification scheme brings in some element of subjective judgment. To discipline this exercise, we consider multiple coarsening taxonomies. Our empirical estimates of the effects of each composite risk index on FDI are then compared across taxonomies to investigate the sensitivity of our results.

Each taxonomy maps the information of all 12 indices into one of the five following composite risk categories:

\footnotetext{
${ }^{19}$ See Ali et al. (2010), Biswas (2002), Daude and Stein (2007), and Li and Resnick (2003) for other examples of this approach to coarsening (i.e., reducing the number of) risk measures based on available measures of institutional quality. We acknowledge Bénassy-Quéré et al. (2007), who criticize this approach based on limits to substitutability within each composite category. See also Globerman and Shapiro (2002) and Wheeler and Mody (1992) for similar arguments.
} 
1. Expropriation Risk Absent

2. Government Efficiency

3. Government Stability

4. Political Accountability

5. Conflicts Absent

Table 1 summarizes the four alternative taxonomies we use to construct the composite indices. The semi-aggregated composites are, in all cases, computed as the simple average across the re-scaled ICRG indices. Composite measures therefore have the same interpretation and theoretical range of 0-10 as the re-scaled ICRG indexes (with larger values corresponding to better institutional quality), with each ICRG variable assigned an equal weight.

Taxonomy 1 defines Expropriation Risk Absent as the average of ICRG's Investment Profile and Law \& Order. ${ }^{20}$ Although the first of these components is closely related to direct expropriation, the second (Law \& Order) captures another aspect of expropriation risk that can occur when laws protecting foreign-owned firms' property rights are weakly enforced. Taxonomy 2 defines Expropriation Risk Absent simply as Investment Profile alone, providing the narrowest definition of expropriation risk possible using the ICRG data. In Taxonomy 3, the expropriation composite is defined the same way as in Taxonomy 1 while moving several ICRG indices from the composite Conflicts Absent and Political Accountability to Government Stability. ${ }^{21}$ Finally, Taxonomy 4 averages ICRG's Government Stability together with the other two ICRG indices (used in Taxonomies 1 and 3 ) to form the most inclusive composite measure of expropriation risk. This inclusive measure reflects an expansive view of unstable political regimes as a potential predictor of government capitulation to political pressure to cancel existing contracts with foreign investors. At the same time, Taxonomy 4 defines the Government Stability composite more narrowly including only ICRG's Socioeconomic Stress Absent. ${ }^{22}$

\footnotetext{
${ }^{20}$ This definition of expropriation risk is also used in Ali et al. (2010).

${ }^{21}$ Taxonomy 3 is intended to correspond to the classification scheme used in Kolstad and Villanger (2008).

${ }^{22}$ See Appendix B for further detail on the 12 ICRG indices and the four taxonomies used to coarsen the set of variables measuring institutional quality. Summary statistics are presented in Online Appendices $2-5$.
} 


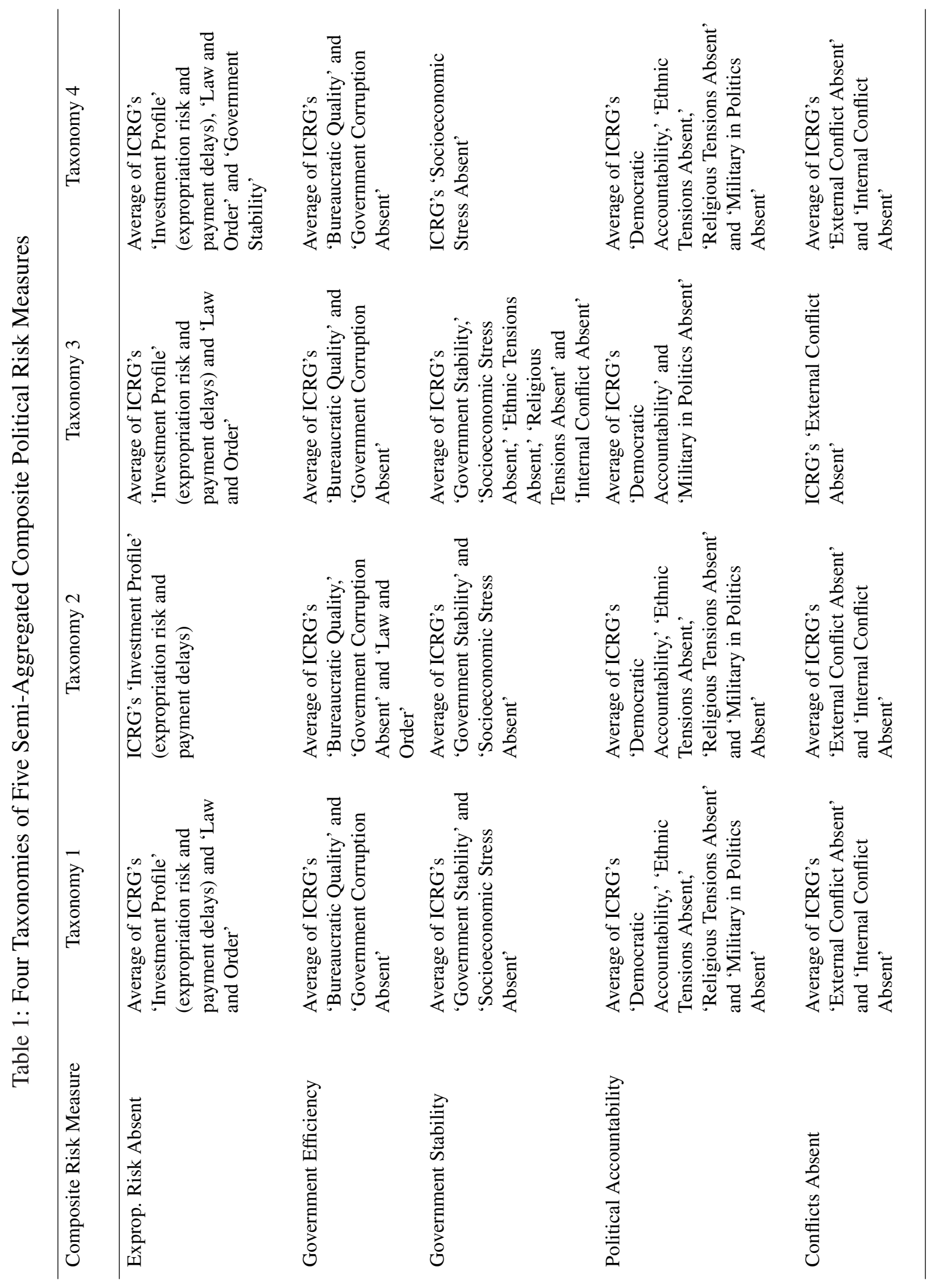




\subsection{Additional Control Variables}

Commonly used controls in empirical models of FDI include GDP or GNI, GNI per capita, GNI per capita growth, macroeconomic stability and other institutional measures such as openness to international trade in the host country. GDP or GNI per capita control for the host country's level of development and other dimensions of institutional quality that are not captured by the ICRG indices. Absolute GNI instead of GNI per capita is used in the literature to capture market size (e.g., Asiedu, 2006; Chakrabarti, 2001; Root and Ahmed, 1979). Market size is generally expected to have a positive impact on FDI, as larger market size implies greater demand and this size advantage attracts more market-seeking foreign investment. Growth in per capita income is also a common control variable (e.g., Schneider and Frey, 1985; Busse and Hefeker, 2007), interpreted as a signal to foreign investors of potential market performance. Openness to international trade is another potentially relevant factor in the foreign firm's decision to invest because trade influences access to essential inputs and revenues from production (e.g., Edwards, 1992; Wheeler and Mody, 1992). The inflation rate, measured as the annual percentage change in the domestic consumer price index (CPI), is used as a proxy for macroeconomic instability; low inflation is hypothesized to reduce uncertainty and increase levels of confidence in the economy, thereby attracting higher FDI inflows. Taxation, which is expected to discourage FDI, is proxied by government size as a share of aggregate output (as in Jensen, 2003; Albuquerque et al., 2005; Ali et al., 2010; Wisniewski and Pathan, 2014). ${ }^{23}$

\subsection{Model Specification}

This section describes our empirical models, each differing in terms of dependent variable and control variables. The general specification for each model is:

$$
\ln (F D I)_{i, t}=\alpha_{i}+\tau_{t}+\mathbf{R}_{i, t}^{\prime} \beta+\mathbf{X}_{i, t}^{\prime} \gamma+\epsilon_{i, t},
$$

where $\mathbf{R}_{i, t}$ is a column vector of variables measuring institutional quality in country $i$ at time $t, \mathbf{X}_{i, t}$ is a column vector of additional control variables, and $\epsilon_{i, t}$ is an error term.

\footnotetext{
${ }^{23}$ Data on government consumption are available for a larger number of countries and time periods compared with direct measures of corporate tax rates. The government sector's relative size as a proxy for taxation is also forward-looking regarding risk of future tax hikes, which may weigh on foreigners' decisions to invest. A list of data sources and available controls are provided in Appendix B.
} 
Country fixed effects, $\alpha_{i}$, absorb unobserved heterogeneity across countries. Coefficients on time indicators, $\tau_{t}$, control for common push factors (e.g., changes in global risk-free interest rates and investor confidence).

As argued in Section 2.1, we believe the appropriate dependent variable is the log of gross inflows per capita. However, because FDI inflows are occasionally negative (e.g., repatriation of profits or disinvestment), we approximate $\ln \left(F D I_{i, t}\right)$ with the inverse hyperbolic sine transformation used by Busse and Hefeker (2007) and described in Section 2.2 .

Using the available data for 83 developing countries over the 32-year period 19842015, each model is estimated using panel fixed effects (FE) and the dynamic BlundellBond generalized method of moments (GMM) estimators. The GMM estimator allows us to estimate dynamic versions of each model while mitigating against potential endogeneity bias. The estimator proposed by Arellano and Bond (1991), commonly referred to as "difference GMM," uses lagged values of the first difference of endogenous variables as instruments. However, lagged levels are often poor instruments for first differences. This problem is addressed by using the system-GMM estimator (Blundell and Bond, 1998), which uses additional moment conditions. We have also considered pooled and random effects (RE) estimators, which are more efficient under the assumption that the unobserved time-invariant effects are either zero or orthogonal to the explanatory variables. However, we did not find strong evidence that these assumptions are satisfied in our data, raising concern that the resulting estimates may be biased. ${ }^{24}$ We therefore focus our discussion on the FE and GMM estimates. (The corresponding random effects estimates reported in an online appendix show that our main conclusions are nevertheless unchanged using the RE estimator.)

Institutional variables typically change slowly, with many values that repeat year over

\footnotetext{
${ }^{24}$ An F-test rejects the joint insignificance of the country fixed effects at conventional levels, indicating that pooled regression estimates could be biased. The Hausman test does not reject the orthogonality assumption of the RE estimator across all models, but the correlation between the covariates and estimated fixed effects is high even for these models (ranging between 0.40 and 0.62 ), suggesting that insufficient statistical power hampers detection of moderate correlation. The RE estimates are associated with smaller standard errors, resulting in statistically significant estimates for political risk variables in a few instances where the FE and GMM estimates are insignificant. However, Guggenberger (2010) shows that standard tests of statistical significance conditional on non-rejection of orthogonality by the Hausman test can be highly misleading in finite samples when there is moderate correlation between the country effects and regressors. (Monte Carlo simulations are run assuming a panel structure and correlations that closely match features of our data. These simulations suggest that a Hausman test correctly rejects orthogonality only 40 per cent of the time, and that tests of statistical significance are highly distorted.)
} 
year. We therefore constructed panel data using a four-year time increment. Each observation is a four-year time average, which provides a maximum of eight time-series observations (when all country-year observations are non-missing). The models estimated are as follows:

(A) Model A uses log net FDI inflow per capita as the dependent variable, as in Busse and Hefeker (2007). This specification is similar to theirs in that it includes two income-related measures as control variables, log of GNI per capita (PPP, current international dollars) and log of growth in GNI per capita, as well as price inflation and a measure of trade openness. Unlike Busse and Hefeker, however, we simultaneously control for all 12 ICRG indexes (instead of including them one at a time) and include government size as a proxy for the level of taxation.

(B) Model B is identical to Model A except that gross FDI inflows per capita replace net FDI inflows per capita as the dependent variable.

(C) Model C is the same as Model B, but instead of including both income variables as controls, only log of GNI per capita is included. Inclusion of this single income variable follows the econometric specifications used by others in the empirical FDI literature (Adam and Filippaios, 2007; Asiedu, 2002; Asiedu and Lien, 2011; Chakrabarti, 2001). The reason for including both income and income growth is to independently control for market size and growth potential. Including two transformations of one income variable may not achieve this objective, however. Insofar as the broader goal is to learn which political institutions most influence FDI inflows, it is the effects of political institutions on the growth potential of the local market that we want to measure. Absorbing some of this growth potential in the local market with a second control variable that is functionally dependent on sameperiod and last-period income introduces multiple methodological issues that Model $\mathrm{C}$ addresses by removing log of GNI growth per capita from the set of explanatory variables.

(D) Model $\mathbf{D}$ provides a more flexible functional form than that of $\mathrm{C}$ by controlling for both market size and level of development. Model D includes the log of GNI and $\log$ of population as explanatory variables. Model D is more flexible than Model C in that the estimated coefficients for $\log$ GNI and (the negative of) log population are unrestricted. 
Model D is our preferred model specification owing to the econometric advantages discussed in Sections 2.1 to 2.4. For purpose of comparison, we also estimate the model with net FDI per capita as the dependent variable in Model A and the alternative righthand-side specifications of Models B and C. Using the estimates based on our preferred model, we rank the quantitative effects of the various political risk indices coded in the vector $\mathbf{R}_{i, t}$ based on respective one-standard-deviation and worst-to-best changes given the empirical standard deviation and range of each measure of institutional quality.

\section{Results}

\subsection{Simultaneous Inclusion of 12 Measures of Institutional Quality}

Estimates corresponding to Models A through D when the full set of 12 ICRG indices is used are reported in Table 2. Fixed effects estimates of Model A are reported in the first column with associated t-statistics calculated using robust standard errors clustered by country. None of the political risk variables are statistically significant in this model. The results from GMM estimation (reported in the first column of Table 3) are not much better, although they do reveal a significant positive effect of improvements in (i.e., lower) religious tensions, as well as a significant negative relationship between net FDI flows and both democratic accountability and law and order. ${ }^{25}$

In Section 2 we considered the potential for model mispecification if net FDI is used as the dependent variable instead of gross FDI flows. This analysis suggested that, when the gross FDI inflow and (reverse) outflow elasticities with respect to a particular dimension of institutional quality are not identical, the associated net FDI elasticity is non-linear and difficult to interpret- theoretically and, by implication, empirically. ${ }^{26}$ In developing countries, expropriation is most often targeted at foreign assets. Therefore, one might hypothesize that expropriation risk has strong effects reducing inward FDI without affecting domestic residents' decisions to move their capital abroad. Comparing Model A (using net FDI) against Models B, C and D (using gross FDI inflows), Tables 2 and 3 are consistent with such a hypothesis.

\footnotetext{
${ }^{25}$ Estimates of Model A when each institutional variable is included separately, one at a time, as in Busse and Hefeker (2007), are reported in Online Appendices 6 to 8. Those results are qualitatively similar to the estimates obtained when all 12 ICRG indices are simultaneously controlled for.

${ }^{26}$ See Appendix D for details.
} 
Table 2: Fixed Effects Estimates of Models A, B, C and D

\begin{tabular}{|c|c|c|c|c|c|c|c|c|}
\hline \multirow[b]{2}{*}{ VARIABLES } & \multicolumn{2}{|c|}{ Model A } & \multicolumn{2}{|c|}{ Model B } & \multicolumn{2}{|c|}{ Model C } & \multicolumn{2}{|c|}{ Model D } \\
\hline & coef & tstat & coef & tstat & coef & tstat & coef & tstat \\
\hline Exprop. Risk Absent & 0.09 & 0.60 & $0.19 * *$ & 2.11 & $0.23 * * *$ & 2.73 & $0.32 * * *$ & 3.50 \\
\hline Law and Order & -0.13 & -0.86 & 0.00 & 0.05 & 0.04 & 0.62 & 0.08 & 1.00 \\
\hline Bureaucratic Quality & -0.24 & -1.26 & -0.08 & -0.62 & -0.06 & -0.50 & -0.15 & -1.39 \\
\hline Corruption Absent & 0.10 & 0.60 & 0.08 & 0.68 & 0.11 & 1.05 & 0.17 & 1.59 \\
\hline Democratic Accountability & -0.10 & -0.83 & 0.01 & 0.06 & 0.03 & 0.41 & 0.00 & -0.03 \\
\hline Military Absent in Politics & 0.07 & 0.77 & 0.05 & 0.59 & 0.05 & 0.63 & 0.08 & 1.18 \\
\hline Ethnic Tensions Absent & -0.08 & -0.70 & -0.03 & -0.49 & 0.00 & 0.05 & -0.01 & -0.18 \\
\hline Religious Tensions Absent & 0.22 & 1.16 & -0.05 & -0.85 & 0.01 & 0.18 & 0.06 & 0.82 \\
\hline Socioecon. Stress Absent & -0.24 & -1.30 & 0.05 & 0.47 & 0.08 & 0.67 & 0.05 & 0.46 \\
\hline Internal Conflict Absent & 0.06 & 0.45 & 0.00 & 0.05 & -0.10 & -1.19 & -0.05 & -0.64 \\
\hline External Conflict Absent & 0.10 & 1.00 & 0.02 & 0.25 & -0.01 & -0.19 & -0.05 & -0.72 \\
\hline Government Stability & 0.12 & 0.81 & $0.14^{*}$ & 1.78 & $0.16^{*}$ & 1.93 & $0.17^{*}$ & 1.77 \\
\hline Gov Expenditure & -0.04 & -0.61 & -0.03 & -0.94 & 0.03 & 0.40 & 0.03 & 0.48 \\
\hline Log Population & & & & & & & -0.84 & -0.66 \\
\hline Log GNI & & & & & & & -0.70 & -1.08 \\
\hline Log GNI per capita & 0.23 & 0.60 & 0.04 & 0.18 & -0.20 & -0.55 & & \\
\hline Log GNI Growth & $0.20^{* * *}$ & 2.68 & $0.12 * *$ & 2.45 & & & & \\
\hline Log Trade & 0.99 & 1.38 & 0.13 & 0.45 & $0.54 *$ & 1.72 & 0.34 & 0.94 \\
\hline Log Inflation & -0.06 & -0.69 & -0.02 & -0.24 & -0.04 & -0.40 & 0.06 & 0.47 \\
\hline No. of Observations & 46 & & 53 & & 60 & & 531 & \\
\hline No. of Countries & 77 & & 8 & & 83 & & 82 & \\
\hline R-squared & 0.2 & & 0.5 & & 0.5 & & 0.4 & \\
\hline
\end{tabular}

${ }^{1}$ The t-statistics are computed using clustered standard errors (clustering by country). All models include country and time effects. The asterisks “***," " ***," and "**” denote statistical significance at the $1 \%, 5 \%$ and $10 \%$ levels, respectively. With 83 countries and eight time points (computed as four-year averages for each variable over the seven non-overlapping four-year windows from 1984-2015), the potential number of observations is 83 (countries) $\times 8$ (four-year periods) $=664$, which would be the sample size if all 83 country-year observations were non-missing for each year in our time horizon. Because of missing data, however, the unbalanced panels include 78 to 83 countries with different numbers of years for which data are available.

2 Model A dependent variable is the natural log of net FDI flows per capita. Model B is identical to Model A, but with gross inflows rather than net flows as the dependent variable. In Model C, the dependent variable is also the natural log of gross FDI inflows per capita, but controlling for only one national income variable. Model D is identical to Model C, but relaxes the restriction on the estimated national income and population relationships by separating log GNI per capita into its component terms. In all models, the dependent variable is approximated by the inverse hyperbolic sine transformation. 
Table 3: GMM Estimates of Models A, B, C and D

\begin{tabular}{|c|c|c|c|c|c|c|c|c|}
\hline \multirow[b]{2}{*}{ VARIABLES } & \multicolumn{2}{|c|}{ Model A } & \multicolumn{2}{|c|}{ Model B } & \multicolumn{2}{|c|}{ Model C } & \multicolumn{2}{|c|}{ Model D } \\
\hline & coef & tstat & coef & tstat & coef & tstat & coef & tstat \\
\hline Exprop. Risk Absent & 0.04 & 0.20 & $0.19 *$ & 1.75 & $0.26^{* *}$ & 2.227 & $0.27 * *$ & 2.28 \\
\hline Law and Order & $-0.55^{* *}$ & -2.26 & -0.03 & -0.41 & 0.02 & 0.23 & 0.05 & 0.46 \\
\hline Bureaucratic Quality & -0.21 & -1.09 & -0.18 & -0.99 & -0.24 & -1.363 & -0.25 & -1.35 \\
\hline Corruption Absent & 0.13 & 0.69 & $0.23 * *$ & 2.03 & $0.18 * *$ & 1.966 & $0.19 * *$ & 1.99 \\
\hline Democratic Accountability & $-0.16^{*}$ & -1.69 & -0.12 & -1.49 & -0.09 & -1.024 & -0.1 & -1.16 \\
\hline Military Absent in Politics & 0.17 & 1.33 & 0.12 & 1.29 & $0.18^{*}$ & 1.934 & $0.18^{*}$ & 1.88 \\
\hline Ethnic Tensions Absent & 0.09 & 0.64 & -0.08 & -1.30 & $-0.12 *$ & -1.948 & $-0.12 *$ & -1.87 \\
\hline Religious Tensions Absent & $0.27 *$ & 1.65 & 0.07 & 0.71 & 0 & 0.055 & 0.01 & 0.11 \\
\hline Socioecon. Stress Absent & 0.12 & 0.53 & 0.11 & 0.66 & 0.07 & 0.51 & 0.07 & 0.52 \\
\hline Internal Conflict Absent & 0.17 & 1.24 & 0.15 & 1.47 & 0.15 & 1.592 & 0.14 & 1.58 \\
\hline External Conflict Absent & 0.16 & 0.73 & -0.03 & -0.32 & -0.14 & -1.123 & -0.15 & -1.17 \\
\hline Government Stability & 0.22 & 1.21 & 0.08 & 0.87 & 0.11 & 1.059 & 0.13 & 1.22 \\
\hline Gov Expenditure & 0.08 & 0.97 & -0.01 & -0.45 & -0.02 & -0.622 & -0.02 & -0.67 \\
\hline Log Population & & & & & & & 0.13 & 0.31 \\
\hline Log GNI & & & & & & & -0.86 & -1.20 \\
\hline Log GNI per capita & -0.32 & -0.72 & -0.15 & -0.46 & -0.58 & -1.085 & & \\
\hline Log GNI Growth & $0.20 * * *$ & 2.64 & 0.08 & 1.37 & & & & \\
\hline Log Trade & 0.05 & 0.05 & 0.53 & 1.14 & 0.52 & 1.159 & $0.76^{*}$ & 1.90 \\
\hline Log Inflation & 0.18 & 1.38 & $0.13 *$ & 1.92 & 0.06 & 0.964 & 0.07 & 0.97 \\
\hline FDI (Lagged) & $0.53 * * *$ & 6.43 & $0.55 * * *$ & 4.77 & $0.56^{* * *}$ & 4.16 & $0.54 * * *$ & 3.99 \\
\hline Constant & -1.97 & -0.36 & -2.62 & -0.97 & 1.51 & 0.363 & 1.02 & 0.11 \\
\hline No. of Observations & 40 & & 479 & & 53 & & 526 & \\
\hline No. of Countries & 76 & & 81 & & 83 & & 82 & \\
\hline No. of Instruments & 51 & & 51 & & 50 & & 51 & \\
\hline Sargan (p-value) & 0.0 & & 0.0 & & 0.3 & & 0.3 & \\
\hline
\end{tabular}

${ }^{1}$ The t-statistics are computed using robust standard errors. All models include time effects. The asterisks “***," “**," and "**" denote statistical significance at the $1 \%, 5 \%$ and $10 \%$ levels, respectively. With 83 countries and eight time points (computed as four-year averages for each variable over the seven nonoverlapping four-year windows from 1984-2015), the potential number of observations is 83 (countries) $\times 8$ (four-year periods) $=664$, which would be the sample size if all 83 country-year observations were non-missing for each year in our time horizon. Because of missing data, however, the unbalanced panels include 78 to 83 countries with different numbers of years for which data are available.

${ }^{2}$ Model A dependent variable is the natural log of net FDI flows per capita. Model B is identical to Model $\mathrm{A}$, but with gross inflows rather than net flows as the dependent variable. In Model $\mathrm{C}$, the dependent variable is also the natural log of gross FDI inflows per capita, but controlling for only one national income variable. Model D is identical to Model C, but relaxes the restriction on the estimated national income and population relationships by separating log GNI per capita into its component terms. In all models, the dependent variable is approximated by the inverse hyperbolic sine transformation. 
In Models B, C and D, Expropriation Risk Absent has a substantial and statistically significant effect on gross FDI inflows in both FE and GMM estimation. A one-unit change in this index is associated with as much as a 33 per cent increase in expected FDI inflows. ${ }^{27}$ Models B to D in Tables 2 and 3 also provide some evidence that Government Corruption, Government Stability and Military in Politics matter for FDI inflows, with significant coefficients at conventional levels for some specifications. Unlike expropriation risk, however, these effects are rather sensitive to the estimator employed. Moreover, Ethnic Tensions Absent has a statistically significant negative impact in the GMM estimates.

The magnitude of the effect of expropriation risk on FDI is both economically and statistically significant. No other effect among the 12 ICRG indices is nearly as large or significant as often. (The exception is government corruption in the GMM estimates of Specification B.) The dominance of expropriation risk in Tables 2 and 3 contrasts with mixed empirical results reported in previous studies. For example, Jensen (2003) finds that expropriation has an insignificant effect on FDI after controlling for democratic institutions. In a sample of African countries, Naudé and Krugell (2007) also find that their measure of expropriation risk has no effect on FDI after controlling for host-country income, inflation, and trade openness. Adam and Filippaios (2007) find a negative effect-expropriation risk reduces FDI—but only in countries where civil liberties are sufficiently strong. One possible reason for inconsistent empirical results could be missing controls for the multiple dimensions of institutional quality. Previous studies without full sets of controls for different dimensions of variation in institutional quality may suffer from omitted variables bias. Obvious among the methodological challenges we face in estimating our models while jointly including 12 or more, possibly correlated, measures of institutional quality is insufficient statistical precision due, at least in part, to multicollinearity.

Collapsing the 12 ICRG indices into five semi-aggregated composite risk measures (as described in the previous section), we aim to improve the precision of the estimates by reducing the number of parameter estimates being asked of the data. Moreover, compared

\footnotetext{
${ }^{27}$ The ICRG indices all have potential ranges of $[0,10]$ and most have standard deviations around 2. The standard deviation of Expropriation Risk Absent is 1.7. (Summary statistics are presented in Online Appendix 2.) Therefore, a one-standard-deviation improvement in Expropriation Risk Absent is associated with an approximate 56 per cent $(=(1 / 3) \times 1.7=0.56)$ increase in inward FDI. A full comparison of simulated effects on expected FDI associated with standardized improvements in each institutional variable is presented in Section 3.2.
} 
with the 12 ICRG indices, the five composite measures of institutional quality are not as correlated, and thus may help to mitigate potential problems of multicolinearity. Moving from 12 to five dimensions of institutional quality, of course, compresses information. Across all taxonomies used in constructing the composite measures, however, no major category of institutional quality from the set of controls is ever omitted. ${ }^{28}$

Table 4 reports Model D estimates based on five semi-aggregated composite measures of institutional quality, grouped by the four taxonomies in Table 1. Among the five composite measures of institutional quality, only expropriation risk is economically and statistically significant across all four taxonomies. The estimates in Table 4 point toward expropriation risk as having the largest and most precisely estimated effects among all institutional effects on FDI (consistent with Tables 2 and 3). ${ }^{29}$

In contrast to the mixed results in this literature, Tables 2, 3 and 4 show a strong and consistently negative relationship between expropriation risk and FDI in the presence of controls that include multiple other dimensions of institutional quality (11 other dimensions in Tables 2 and 3 and four others in Table 4). Our results suggest that expropriation is an especially (if not singularly) important factor in understanding the positive effect of higher institutional quality on capital flows documented by Alfaro et al. (2008) and others. Further, we do not find evidence that FDI is positively associated with income per capita.

Next, we investigate which dimensions of institutional quality are likely to have the largest impacts on FDI based on the variance in institutions across countries. The counterfactual scenario in question is: If a country with average characteristics in all other respects were to succeed in improving a single political risk variable by one standard deviation or, more dramatically, achieving a worst-to-best improvement (based on each political risk variable's empirical range), then how large would the response of foreign investors' FDI be on average? To answer this question, the next section extends our investigation by using the coefficient estimates from Tables 2, 3 and 4 together with each political risk variable's empirical standard deviation and range to compare simulated effects corresponding to related sets of counterfactual improvements in the political risk vari-

\footnotetext{
${ }^{28}$ As a robustness check, we also re-estimate the model based on principal components. (See Section 3.3 and Online Appendices 9A and 9B for details.)

${ }^{29}$ Findings in Table 4 are consistent with those of Ali et al. (2010), who measure expropriation risk based on a composite index identical to the one we use in Taxonomies 1 and 3 . They find that strength of property rights significantly increases FDI even after controlling for institutional variables such as democracy, corruption, political stability, and socioeconomic tensions.
} 


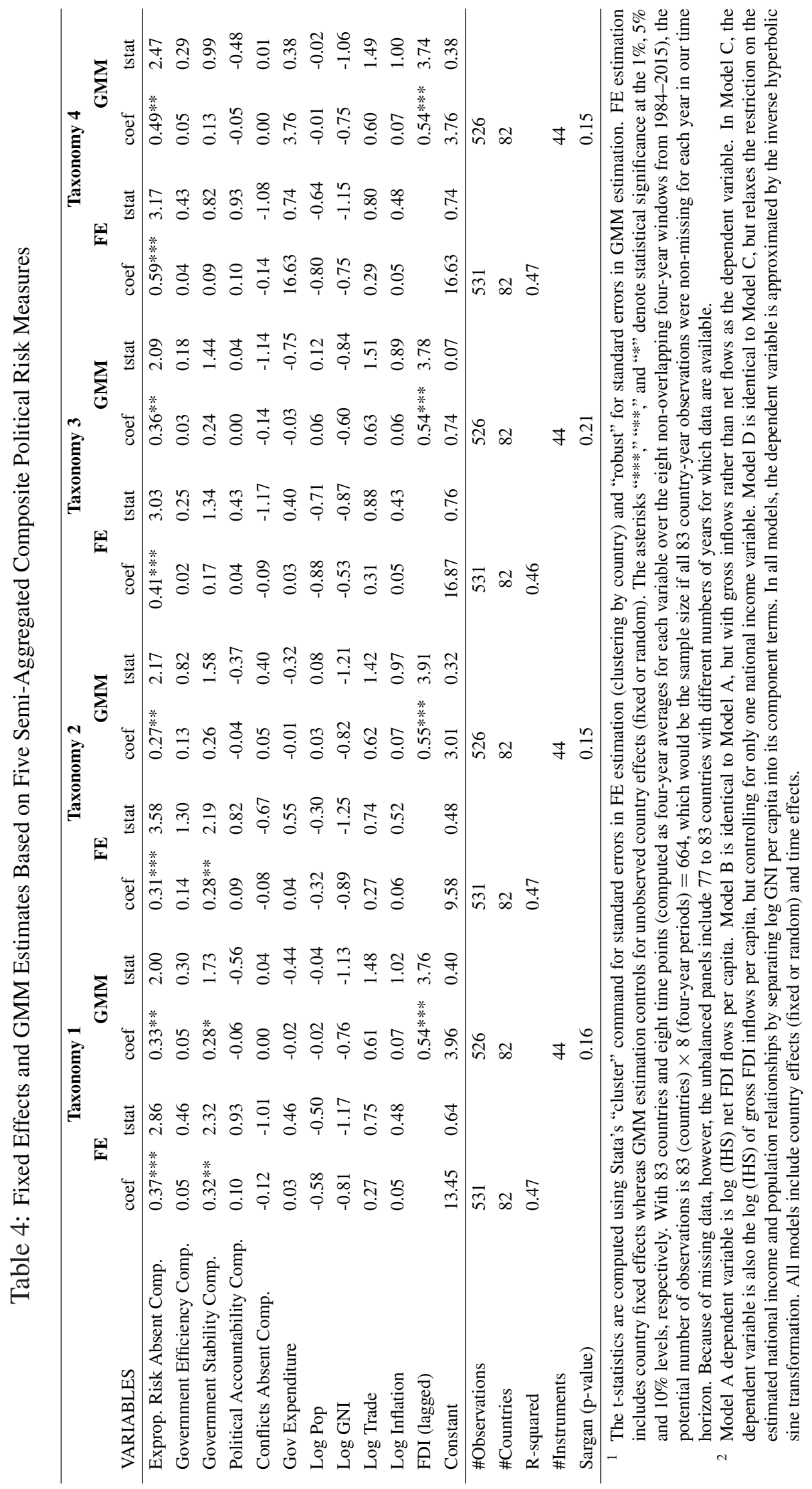


ables. In contrast to simply ranking the estimated marginal effects, these counterfactuals take into account potential differences in the average scope for institutional improvement across the different institutional quality indicators based on their empirical distributions. ${ }^{30}$

\subsection{Ranking the Importance of Political Risk Variables}

Taking the perspective of a foreign investor deciding how to allocate capital across highstakes investment opportunities overseas, the simulations in this section multiply the coefficients estimated in Tables 2 and 3 by changes in each political risk variable corresponding to the counterfactuals just described. Holding $\mathbf{X}_{i, t}$ in Equation (1) constant, the expected percentage change in FDI resulting from a given improvement in relative country risk $\Delta R$ is given by:

$$
\% \Delta F D I \approx(\exp [\hat{\beta} \times \Delta R]-1) \times 100
$$

where $\hat{\beta}$ is the estimated coefficient corresponding to the associated political risk index. Denoting the statistical standard deviation operator as $S D(\cdot)$ and the empirical range as $\max _{i}\left(R_{i}\right)-\min _{i}\left(R_{i}\right)$, values for which are contained in the summary statistics of Online Appendices 2 through 5 , the counterfactual improvements in institutional quality $(\Delta R)$ take on two values $\left(\Delta R_{a}\right.$ and $\left.\Delta R_{b}\right)$ :

$$
\Delta R_{a}=S D(R), \quad \text { and } \quad \Delta R_{b}=\max _{i}\left(R_{i}\right)-\min _{i}\left(R_{i}\right)
$$

Table 5 provides rankings of simulated percentage changes in FDI, $\hat{\beta} \times \Delta R$, for both the fixed-effects and GMM estimates. ${ }^{31}$ Table 5 presents simulated effects of the two standardized improvements in measures of institutional quality based on the models that include all 12 ICRG indices. Online Appendix 10 presents analogous simulated effects using five semi-aggregated composite measures of institutional quality instead of the 12

\footnotetext{
${ }^{30}$ One dimension of institutional quality could have a significant impact on FDI at the margin but account for a comparatively small proportion of observed variation in FDI if, compared with other dimensions of institutional quality, countries exhibit very little difference in quality on average (owing to, for example, all countries scoring near to the upper or lower bounds of the feasible index range).

${ }^{31}$ Assigning ranks to simulated effects that are very close in magnitude is potentially problematic because ordinal differences may be assigned to effect sizes that are statistically indistinguishable given the precision of estimation afforded by the data. We apply a threshold difference of one percentage point and assign different ranks (and tied rankings otherwise) only to simulated effects that differ by more than one percentage point (which we believe is a reasonable threshold for economic significance).
} 
ICRG indices.

Compared with all other measures of institutional quality in the model, the simulated effect of expropriation risk tends to be the largest and therefore most economically significant for both the fixed-effects and GMM model estimates. ${ }^{32}$ According to Table 5, a one-standard-deviation improvement (i.e., reduction) in expropriation risk is associated with a predicted increase in FDI of 58-72 per cent. Worst-to-best simulated effects on the right-hand side of Table 5 suggest that if one could improve expropriation risk from the lowest percentile (Zimbabwe) to the highest (Czech Republic), then the predicted increase in FDI inflows would be 990-1,600 per cent. The only other dimensions of institutional quality that appear to have a substantive positive impact on FDI are Government Stability (FE estimates), and Corruption Absent, and Military Absent in Politics (GMM estimates); however, the simulated effect of each of these factors tends to be much smaller than that of Expropriation Risk. ${ }^{33}$

\subsection{Robustness Checks}

In addition to the commonly used controls in the literature (GNI, GNI per capita, trade, macroeconomic stability), our analysis so far does not include additional controls that others have found to be important determinants for FDI. For example, quality of infrastructure and human capital formation appear to be potentially important controls to include in empirical models of FDI (Asiedu, 2002; Asiedu et al., 2009; Ali et al., 2010). We examined whether our empirical results are robust to the inclusion of several additional controls: number of telephone lines per 100 people and secondary school enrolment ratios. These robustness checks indicate that the model estimates are insensitive to the inclusion of these additional controls, and the overall picture remains unchanged across alternative model specifications. (See Online Appendices 11 and 12 for further detail.)

Remaining robustness checks reflect the methodological tension between including

\footnotetext{
${ }^{32}$ Empirical ranges and standard deviations use the same observations that were used to estimate each respective model. Online Appendices 2-3 provide summary statistics for the Model D estimation sample used in Table 5 and in Online Appendix 10. Online Appendices 4 and 5 report summary statistics for all available observations for the 83 countries in our sample that are listed in Table B2 of Appendix B.

${ }^{33}$ In Online Appendix 10, a one-standard-deviation improvement of the composite measures of Expropriation Risk is predicted to increase FDI by 58 per cent to 125 per cent (across Taxonomies 1 through 4 estimated by FE and GMM). Across all 16 sets of estimates ( 2 estimators $\times 4$ taxonomies $\times 2$ empirical range measures), expropriation risk ranks first in terms of FDI impact, again confirming that the semi-aggregated composite measures of expropriation risk have a relatively pronounced effect on foreign investors' decisions to invest.
} 


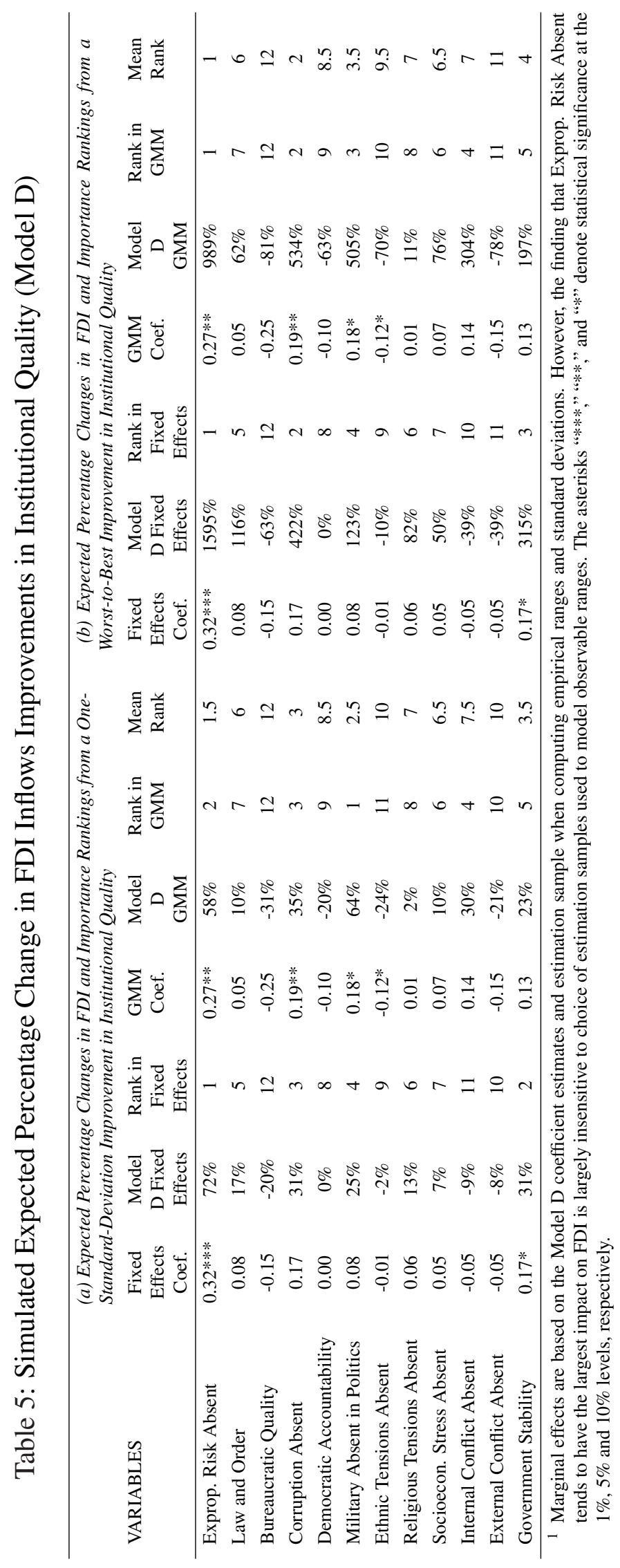


multiple dimensions of institutional variation on the one hand and dealing with the highdimensionality and multicollinearity on the other, which motivates the varied model specifications found in the empirical FDI literature. We began with high-dimensional models that simultaneously included all 12 ICRG indices measuring institutional quality. Next, we compressed this 12-dimensional variation in institutional quality into five dimensions based on the five composite measures. As a further check, we ran principal component analysis on the 12 ICRG indices, which produced three linear combinations with associated eigenvalues greater than 1. Our Model D specification with those three principal factors produces just one large and statistically significant effect whose size is similar to that of expropriation risk in our earlier models. (See Online Appendix 9.) Although it is tempting to interpret the significant principal factor, in which ICRG Expropriation Risk is among the four largest loadings, as something akin to expropriation risk involving abrupt risk of total loss, the mix of other factor loadings makes the meaning of such models somewhat unclear. Additional robustness checks include estimating the effects when including only one ICRG index at a time (without the other 11) as in Busse and Hefeker (2007). This exercise suggests that their choice of dependent variable (i.e., net FDI), rather than the decision to exclude correlated political risk variables among the set controls, accounts for the weak relationship between FDI and expropriation risk in their analysis. (Refer to Online Appendices 6, 7 and 8 for details.) Simulations based on these "one-at-a-time" model estimates support the same conclusion, namely, that expropriation risk has a much larger effect on gross inflows relative to other dimensions of political risk.

\section{Expropriation of FDI in the Presence of Multiple Political Risks: A Simple Model}

In this section we present a simple, stylized model of FDI in the presence of three categories of political risks in the host country that offers a theoretical perspective on the em-

pirical results presented in the previous section. By extending the standard, endogenous expropriation framework to include additional institutional frictions normally absent in such models, we demonstrate a novel implication concerning the variable impact of such 
frictions on FDI flows under different expropriation regimes. ${ }^{34}$ In particular, the model predicts that, when there is a nontrivial threat of outright confiscation of FDI assets, foreign investment unambiguously increases on the margin with a strengthening of contract enforcement, but does not necessarily respond to improvements in other dimensions of institutional quality, and may even decrease in response to such improvements. This prediction is consistent with a muted and potentially ambiguous impact of institutions other than expropriation risk (such as redistributive taxation or regulatory and operational risks) on FDI when the perceived risk of expropriation of foreign investors' assets is sufficiently high. The intuition is that regulatory and political risks decrease the expected value of the foreign-owned asset, which in turn reduces the host country's incentive to expropriate, making direct investment more attractive.

The model's three-category taxonomy of political risks provides a minimally rich theoretical framework for analyzing interactions in which one institutional variable modulates or attenuates the effects of others on FDI. The three broad categories of political risks (i.e., host-country institutions) are:

1. Redistributive Taxation, which includes institutional or legal factors relating to the obligations of foreign investors to transfer the benefits from multinational production to the host country; ${ }^{35}$

2. Regulatory Burdens and Government Inefficiency, including factors that result in deadweight loss, which adversely influence the value of investor assets ex post (e.g., onerous or inefficient licensing procedures, other bureaucratic frictions, corruption, political instability or unrest); ${ }^{36}$ and

\footnotetext{
${ }^{34} \mathrm{We}$ are not the first to introduce other dimensions of institutional quality in models of endogenous expropriation. (See Azzimonti and Sarte, 2007; Koessler and Lambert-Mogiliansky, 2014; Hajzler and Rosborough, 2016, for joint theories of expropriation, corruption, and democratic accountability.) However, these papers are more narrowly focused on specific causal connections between contract transparency, government corruption and investor property rights. Most models of expropriation of FDI also include some form of direct taxation by the host country, endogenously determined in equilibrium as a function of expropriation risk. Our analysis instead considers an exogenous propensity to tax and redistribute (which may depend on, among other things, heterogeneous domestic politics and institutional histories).

${ }^{35}$ For evidence on the potential negative relationship between government taxation (or consumption) and FDI, see Jensen (2003), Ali et al. (2010), Wisniewski and Pathan (2014), and Wei (2000), among others.

${ }^{36} \mathrm{An}$ extensive literature has examined how FDI is influenced by various categories of political risk falling under this category. Notable examples include government corruption (Wei, 2000; Egger and Winner, 2005; Hakkala et al., 2008), uncertainty associated with various types of political regimes (Jensen, 2003; Li and Resnick, 2003; Busse, 2004; Kolstad and Villanger, 2008; Wisniewski and Pathan, 2014), and regulatory risk such as onerous or nontransparent licensing procedures (Gastanaga et al., 1998; Naudé and Krugell, 2007).
} 
3. Expropriation Risk, or weak contract enforcement, capturing the risk of a forced transfer of foreign investor assets to the state or host-country public, either as a result of direct government action or the unwillingness of the government to uphold the protection of foreign investor property rights.

The environment we consider features identical, competitive, risk-neutral foreign investors and a risk-neutral government (who acts on behalf of a representative domestic agent or voter) of a small open economy with a foreign investment opportunity. Foreign investors choose optimal direct investment levels to maximize expected profits, taking the investment decisions of other foreign investors as given. The host-country government aims to attract foreign investment to maximize the host country's income. ${ }^{37} \mathrm{We}$ adopt the standard assumption in the imperfect FDI contract enforcement literature that the government is unable to commit to not seizing all of the foreign investors' assets once investments have been made. ${ }^{38}$ Specifically, the government confiscates all foreign capital whenever its aggregate value exceeds the cost of expropriating.

In the fully dynamic, repeated game environments of Cole and English (1991), Aguiar et al. (2009), and Stroebel and Van Benthem (2013), the cost of expropriating is permanent exclusion from international capital markets (i.e., loss of reputation for honoring contracts). ${ }^{39}$ Without loss of generality, we follow Eaton and Gersovitz (1984), Tomz and Wright (2010) and Hajzler (2014) and consider a static (two-period) game between foreign investors and a host-country government. ${ }^{40}$ In this setup, the cost to expropriating is taken to be exogenous. This expropriation penalty can be interpreted as both the repu-

\footnotetext{
${ }^{37}$ Equivalently, a risk-neutral host-country government or agent maximizes its utility. We do not formally consider how the results may vary with alternative welfare functions exhibiting risk aversion. However, assuming risk neutrality ensures that expropriation is more tempting when the return on investment is high and the host country's revenues are a fixed share of firm revenues or profits (see Cole and English, 1991, for details). If instead the host-country agent were assumed to be sufficiently risk averse, the temptation to expropriate would be higher when firm revenues are relatively low and a binding threat of expropriation, as described below, would instead be characterized by a bound on investor returns from above rather than from below.

${ }^{38}$ See, among others, Eaton and Gersovitz (1984), Cole and English (1991), Thomas and Worrall (1994), Albuquerque (2003), Aguiar et al. (2009), Tomz and Wright (2010), Stroebel and Van Benthem (2013) and Hajzler (2014).

${ }^{39}$ When cutting off all future investment cost is the maximum (trigger strategy) punishment that investors can impose, the cost to the host country is decreasing in the representative agent's (or government's) discount factor and increasing in the degree of risk aversion, since there is an insurance motive for accessing international capital markets when the host-country agent is risk averse. However, even if the host-country agent is risk-neutral, a loss in expected future FDI inflows may be costly if FDI is associated with more efficient technology, as assumed in Stroebel and Van Benthem (2013) and Opp (2012).

${ }^{40}$ In the fully dynamic environments considered by Cole and English (1991) and Stroebel and Van Benthem (2013), exogenous states are assumed to be independently and identically distributed (i.i.d.) over time
} 
tation cost associated with loss in future foreign investment as well as any costs incurred by bringing foreign operations under state control, including legal costs associated with international arbitration claims against the host country, the use of less productive technologies, and potential diplomatic or economic sanctions imposed by investor country governments (such as relinquished aid flows or preferential trade access).

\subsection{Basic Environment}

We consider a small open economy with two sectors. As in Cole and English (1991) and Aguiar et al. (2009), one sector has production technology that employs capital (possibly from foreign investment subject to expropriation). A second "traditional" sector employs only a domestic factor. ${ }^{41}$ For simplicity, we assume that the capital-employing sector is populated entirely by foreign multinationals. Foreign firms combine foreign capital $K_{f}$ and domestic labor $L_{f}$ to produce the numeraire good according to the constant returns to scale technology $Y=z F\left(K_{f}, L_{f}\right)$ (which can be sold domestically or exported at world price $p_{y}=1$ ), where $z>0$ is a stochastic total factor productivity parameter. It will be convenient to normalize all quantities by the number of workers in the foreign-firm sector: output per worker in this sector can be expressed as a strictly concave function of capital per worker: $y=Y / L_{f}=z f(k)$, where $k=K_{f} / L_{f} \geq 0$. The traditional sector, by contrast, is populated entirely by domestic firms that employ labor with constant marginal product $w$ (equal to the economy-wide real wage rate). The distribution of the productivity parameter $z$ describes the likelihood that governmental institutions or other external political factors might interfere with the efficient operation of the project, thereby decreasing the value of FDI projects, as given by the differentiable $\mathrm{CDF}, \Gamma(Z)$, and PDF, $\gamma(Z)$, with continuous support $[\underline{z}, \bar{z}], 0 \leq \underline{z}<\bar{z} \leq \infty$. The host-country government taxes foreign investors' revenue at the rate $\tau \in[0,1)$, which is decided before

and the continuation value of the contract to either party is independent of the current period state. This implies that government's and investors' strategies are time-invariant and the essential features of the contract can be captured within a static framework. In other models (e.g., Phelan, 2006; Thomas and Worrall, 1994), a two-period model no longer provides a good approximation of equilibrium investment and expropriation dynamics.

${ }^{41}$ In Cole and English (1991) and Aguiar et al. (2009), the existence of this traditional sector is needed to bound from below the host-country utility in autarky for any degree of relative risk aversion. In our analysis, the traditional sector provides a convenient tool for capturing differences in host-country labor productivity that potentially affect the benefits received from foreign investment contracts via the equilibrium wage rate. 
the foreign investor installs capital and before the institutional shock is realized. ${ }^{42}$

The analysis considers two periods: an initial period where foreign investors decide how much to invest, and a subsequent period when uncertainty over $z$ is resolved and, once $z$ is known, the host-country government chooses whether to expropriate foreign investor assets, output is produced, and taxes and wages are paid. An expropriating government confiscates all foreign capital, acquiring 100 per cent of the output from the foreign sector, but also incurs a penalty (proportional to the scale of foreign operations) $C=c \times L_{f}$, where $c>0 .{ }^{43}$ In the event of expropriation, the government also forgoes tax and wage payments from the foreign firm (because the wage bill is paid by the new domestic owner of the seized productive asset).

The parameter $\tau$ captures the host country's exogenous political leaning toward redistribution (i.e., risk category 1). Regulatory burdens and government inefficiency (category 2) are captured by the distribution $\Gamma(z)$, which FDI investors could, for example, rank by first-order stochastic dominance. Finally, the magnitude of $c$ is interpreted as the relative strength contract enforcement, and hence is an inverse measure of the exogenous determinants expropriation risk (category 3 ), such that a host government described by a low value of $c$ is more tempted to expropriate FDI, all else being equal.

\subsection{Equilibrium Strategies}

We denote the realized period-2 payoff (ex post) for the representative foreign investor as $V$ and for the host-country government as $W$ (normalized by the number of workers in the foreign firm sector), respectively:

$$
V(k)= \begin{cases}(1-\tau) z f(k)-w-(1+r) k & \text { if } z \leq z^{*}(k), \\ -(1+r) k & \text { if } z>z^{*}(k),\end{cases}
$$

\footnotetext{
${ }^{42} \mathrm{~A}$ revenue tax could represent a mining royalty or extraction tax. The statics we report subsequently are generalizable to the case of a tax on profit. The main results do not depend on the assumption that $\tau$ is known at the time of investment, however. The assumption that $z$ is the only source of uncertainty simplifies the analysis. Analogous results can be obtained in a version of the model with no uncertainty (i.e., when $z$ is drawn from a degenerate distribution). The main difference is that optimal foreign investment in the non-stochastic version of the model is always chosen to ensure that government never expropriates in equilibrium.

${ }^{43}$ This assumption ensures that the degree of expropriation risk, which is inversely related to the size of the expropriation penalty, is independent of the relative size of each sector (measured here in terms of employment).
} 
and

$$
W(k)= \begin{cases}\tau z f(k)+w, & \text { if } z \leq z^{*}(k), \\ z f(k)-c, & \text { if } z>z^{*}(k),\end{cases}
$$

where $r$ is the world risk-free rate of return on capital and $z^{*}(k)$ denotes the threshold value of $z$ (given $k$ ) above which the host country chooses to expropriate, defined as:

$$
\tau z^{*} f(k)+w=z^{*} f(k)-c \Rightarrow z^{*}(k)=\frac{w+c}{(1-\tau) f(k)} .
$$

If the realized value of $z$ is sufficiently large, $z>z^{*}(k)$, then it is optimal for the host country to expropriate. The probability that foreign capital is expropriated in equilibrium, denoted $\pi$, is a decreasing function of the government's threshold $z^{*}(k): \pi=$ $1-\Gamma\left(z^{*}(k)\right)$. By choosing $k$ very small, the threshold $z^{*}(k)$ becomes arbitrarily large, reducing the risk of expropriation to zero whenever the distribution of $z$ has a bounded support. If the investor's optimal choice of $k$, denoted $k^{*}$, is such that $z^{*}\left(k^{*}\right) \geq \bar{z}$, then $\pi=0$ and we say that the investor faces a non-binding threat of expropriation. On the other hand, if $\underline{z}<z^{*}\left(k^{*}\right)<\bar{z}$, then $\pi>0$ and we say that the investor faces a binding threat of expropriation. We demonstrate that constrained optimal FDI responds differently to marginal changes in taxation and other institutional risk depending on whether the threat of expropriation is binding, which in turn depends on the parameters of the model that describe the host country's institutional environment (notably the cost of expropriating, $c$ ).

Taking $z^{*}$ as given, the representative foreign investor chooses $k$ in the first period to maximize expected profits per unit of labor employed:

$$
\max _{k \geq 0} \Gamma\left(z^{*}\right)\left\{(1-\tau) \mathbb{E}\left[z \mid z \leq z^{*}\right] f(k)-w\right\}-(1+r) k
$$

where

$$
\mathbb{E}\left[z \mid z \leq z^{*}\right]=\frac{1}{\Gamma\left(z^{*}\right)} \int_{\underline{z}}^{z^{*}} z d \Gamma(z) .
$$

Assuming an interior solution to the foreign investor's problem that achieves non-negative profit, the optimal choice of $k$ (given $\Gamma, \tau, c, r$ and $w$ ) is the solution to:

$$
\left(\int_{\underline{z}}^{\min \left\{z^{*}(k), \bar{z}\right\}} z d \Gamma(z)\right)(1-\tau) f_{k}(k)=1+r
$$


where $z^{*}(k)$ (as defined by (4)) is strictly decreasing in $k$. For some parameter values, expected profits may be negative at the optimal solution in (5). In this case, optimal foreign investment, denoted $k^{*}$, is zero, reflecting the non-negativity constraint on $k$, and zero profit is achieved with certainty.

If the threat of expropriation is non-binding, then $\min \left\{z^{*}(k), \bar{z}\right\}=\bar{z}$ and $\Gamma\left(z^{*}\right)=1$. In this case, $k^{*}$ is the unconstrained optimal ("first best") solution to $(1-\tau) \mathbb{E}[z] f_{k}\left(k^{*}\right)=$ $1+r$, where $\mathbb{E}[z]$ is the unconditional expectation of $z$. That is, $\Gamma\left(z^{*}\right)=1(\pi=0)$ results in a familiar first-order condition characterizing the investment behavior of foreign investors who face no material risk of expropriation with straightforward monotonic comparative statics with respect to any improvement in a given political institution.

When there is a threat of expropriation, however, then $\min \left\{z^{*}(k), \bar{z}\right\}=z^{*}(k)$ and $\Gamma\left(z^{*}\right)<1$. The resulting optimal FDI, $k^{*}$, responds monotonically to the direct institutional shock of changes in $c$ but has comparative statics of indeterminate sign with respect to the other two sources of institutional variation, as shown below. Given the exogenous tax rate, wage rate and cost of capital, the host country's optimal expropriation strategy $z^{*}(k)$ and foreign investor's optimal investment decision $k^{*}$, defined implicitly by the piecewise function that solves (5), fully characterize the equilibrium when the threat of expropriation is binding.

\subsection{Comparative Statics: FDI Responses to Different Political Risks}

The comparative statics in this section illustrate how foreign investment is predicted to respond to the three types of risk in the model. It is straightforward to verify that foreign investment is positively related to strength of contract enforcement in this environment. We see from (5) that, because $z^{*}(k)$ is decreasing in $k$ and increasing in $c$, an increase in $c$ (for a given $k$ ) increases the expected marginal product of capital (net of tax) whenever there is a binding threat of expropriation (that is, when $\min \left\{z^{*}(k), \bar{z}\right\}=z^{*}(k)$ ), which results in an increase in optimal FDI $\left(k^{*}\right)$. This relationship can be shown formally by substituting for $z^{*}(k)$ into the FDI investor's first-order condition (5) and fully differentiating (using Leibnitz' Rule) with respect to $c$, yielding:

$$
\frac{\partial k^{*}}{\partial c}=\frac{z^{*}\left(k^{*}\right) \cdot \gamma\left(z^{*}\left(k^{*}\right)\right)}{f_{k}\left(k^{*}\right) \cdot\left(z^{*}\left(k^{*}\right)\right)^{2} \cdot \gamma\left(z^{*}\left(k^{*}\right)\right)-\frac{f_{k k}\left(k^{*}\right) f\left(k^{*}\right)}{f_{k}\left(k^{*}\right)} \cdot\left(\int_{\underline{z}}^{z^{*}\left(k^{*}\right)} z d \Gamma(z)\right)}>0 .
$$


This expression is positive given that $\gamma(z)=\partial \Gamma(z) / \partial z>0$ and given our concavity assumption, $f_{k k}=\partial^{2} f(k) / \partial k^{2}<0$, which implies the denominator is positive. The numerator is equal to the marginal decrease in the probability of expropriation from an increase in $c$, scaled by after-tax revenues (evaluated at $z=z^{*}$ ). Intuitively, an increase in the cost of expropriation decreases the probability of expropriation and thus increases the investor's expected return from the project revenues, all else being equal. This unambiguously increases the incentive to invest. ${ }^{44}$

Next, consider the effects of an increase in $\tau$ on foreign investment. If the threat of expropriation is non-binding, then the conditional expectation in large brackets of condition (5) equals $\mathbb{E}[z]$ for all $\tau$ and the standard negative relationship between the tax rate and optimal investment emerges. Once we allow for strictly positive expropriation risk, however, then $\min \left\{z^{*}(k), \bar{z}\right\}=z^{*}(k)$, which implies that the conditional expectation in the first-order condition now depends on $k^{*}$ and $\tau$, and that the total effect of $\tau$ on FDI becomes ambiguous (summarized by the following result with formal proof in Appendix C):

Result 4.1. Given the distribution of institutional quality unrelated to expropriation and redistribution $(\Gamma(z))$, if the threat of expropriation binds $\left(z^{*}\left(k^{*}\right)<\bar{z}\right)$, then an increase in tax rate $(\tau)$ may either increase or decrease optimal FDI $\left(k^{*}\right)$.

Intuitively, when an investor faces a sufficient threat of expropriation, corresponding to $z^{*}\left(k^{*}\right)$ lying in the strict interior of the support of $z$, the impact of $\tau$ on FDI can be decomposed into a direct negative effect on the marginal after-tax returns from investment and an indirect positive effect on ex ante expected returns resulting from a lower expropriation probability at a given level of investment. The negative effect of an increase in the tax rate on investor returns may be more than offset by the positive effect from a decrease in the host-country government's temptation to expropriate, resulting in either smaller or larger optimal FDI, as represented by $k^{*}$.

We can show a similarly ambiguously signed response of optimal FDI with respect to exogenous shocks to $z$. Improvements in the distribution function $\Gamma(z)$ representing category-2, institutional quality (i.e., regulatory burden and government efficiency) may, counterintuitively, result in lower levels of optimal investment once there is a strictly positive probability of expropriation. Positive shocks to $z$ do not entail any direct loss in gov-

\footnotetext{
${ }^{44}$ The two terms in the denominator capture decreasing expected returns to higher investment, the first term associated with an amplification of expropriation risk arising from larger investment and the second due to concavity in production.
} 
ernment revenues. Nevertheless, the possibility that such improvements elicit responses in optimal FDI with an ambiguous sign is remarkable and highly relevant to the empirical investigation of expropriation in the presence of variation in other dimensions of institutional quality. ${ }^{45}$ When there is no threat of expropriation (because $z^{*}\left(k^{*}\right)$ is strictly above the support of $z$ ), then any increase in this category of risk would unambiguously reduce optimal investment $k^{*}$ through a reduction in the unconditional expectation of $z$. However, when the threat is binding, the ambiguous relationship between the expected value of $z$ and optimal FDI for a particular type of distribution function, $\Gamma(z)$, re-emerges:

Result 4.2. If the threat of expropriation does bind $\left(z^{*}\left(k^{*}\right)<\bar{z}\right)$, then an improvement (i.e., first-order stochastic dominance) in the distribution $(\Gamma(z))$ of institutional quality unrelated to expropriation and redistribution may either increase or decrease optimal $\operatorname{FDI}\left(k^{*}\right)$.

See Appendix $\mathrm{C}$ for derivation of this result.

In this sense expropriation risk potentially dominates other forms of institutional quality. If the threat of expropriation is sufficiently large, then increased institutional quality (i.e., reduction of a different dimension of political risk, such as government bureaucracy or redistribution risk) may have little effect on foreign investment. Such improvements in institutional quality may also counterintuitively increase expropriation risk by making foreign-owned assets more attractive to steal.

A final theoretical prediction related to the empirical findings concerns the relationship between average labor productivity and FDI. Condition (4) is that, when the threat of expropriation is binding, the temptation to expropriate declines and FDI increases with the wage to labor, $w$. (By construction, FDI is independent of $w$ in the absence of expropriation risk as long as profits are positive.) Intuitively, a higher average wage implies a higher payment for labor which the host country is unable to recoup from the investor in the event of an expropriation. Although the model is too simple to fully capture the relationship between labor productivity and other incentives to invest, it suggests a channel through which policies in relatively high-risk countries that increase average labor productivity can raise FDI. In the statistical models estimated in the previous section,

\footnotetext{
${ }^{45}$ To show this, we represent differences in the distribution function $\Gamma(z)$ using the concept of first-order stochastic dominance. We suppose that institutional risk in Country A exceeds that of Country B if and only if $\Gamma_{A}$ first-order stochastically dominates $\Gamma_{B}$ (denoted $\Gamma_{A}(Z) \leq \Gamma_{B}(Z)$, with strict inequality for some $Z)$. Supposing that this property is governed by a single parameter $\alpha$, such that $\Gamma\left(Z, \alpha_{1}\right) \leq \Gamma\left(Z, \alpha_{2}\right) \Leftrightarrow$ $\alpha_{1}>\alpha_{2}$ (with strict inequality for some $Z$ ), then an increase in country risk is captured by a reduction in $\alpha$.
} 
income per capita is expected to be highly correlated with the economy-wide stock of human capital and average returns to labor. Although our empirical results do not reveal a statistically significant empirical relationship between this variable and FDI, our robustness regression model estimates presented in Online Appendices 11 and 12 provide some evidence that human capital, proxied by average years of schooling, is positively associated with FDI. One potential reason for the weak statistical relationship between income per capita and FDI is that the former is also positively associated with unobserved dimensions of institutions that would be predicted to have a similarly ambiguous impact on FDI. Moreover, alternative theoretical perspectives on expropriation risk suggest that higher levels of human capital can discourage FDI. If higher labor productivity is tied to specific skills that enable the host country to operate expropriated foreign firms more productively, the efficiency loss associated with expropriation declines with increased human capital, potentially contributing to higher risk (refer to Eaton and Gersovitz, 1984, for details).

\section{Discussion}

Our simple theoretical model provides one interpretation for the dominant role of strength of contract enforcement in explaining FDI flows to developing economies and, in particular, the insignificant (or even negative) relationships between other measures of institutional quality and FDI once expropriation risk is taken into account. To the extent that proxies for expropriation risk succeed at capturing the political and economic costs (as represented by parameter $c$ in our theoretical model) incurred by expropriation, our model implies that the net effects of taxation and other political risks on FDI are ambiguous when expropriation is sufficiently costly.

However, we stress that, because the ICRG measure of expropriation risk is based on the subjective judgements of foreign affiliate stakeholders and other experts, the resulting proxy for expropriation risk likely reflects some indirect effect of other dimensions of institutional quality on FDI, arising from their influence on expropriation incentives (emphasized by our model). That is, the estimated relationship between expropriation risk and FDI may also capture such indirect effects. Accordingly, the main insight from our theoretical model can be stated more generally as follows: When the risk of asset seizure is salient in foreign investors' minds, the primary channel by which other dimensions of host-country institutional quality will influence FDI is through their influence on 
expropriation risk.

This view also suggests that several dimensions of institutional quality considered in our statistical models of FDI are potentially important predictors of expropriation. Although we do not attempt to unbundle the factors underlying country differences in expropriation risk in this paper, several explanations for the variation in foreign investors' property rights protection have been proposed in the existing literature. For example, political instability and polarization is a determinant of expropriation risk in the theoretical model of Hajzler (2014). The model is calibrated for 38 developing and emerging markets, and the ICRG's measure of government stability is a key parameter identifying 12 economies (of which 10 are located in Latin America) with moderate-to-high probabilities of expropriating FDI. ${ }^{46}$ Furthermore, Jensen (2008), Li (2009) and Harms and an de Meulen (2013) show that characteristics of host-country democratic institutions help to explain the likelihood that foreign investments are expropriated. Both Jensen (2008) and Li (2009) show that fewer political constraints on the chief executive tend to increase expropriation risk. In contrast, Harms and an de Meulen (2013) find that expropriation risk is higher in democracies when demographics imply asymmetric gains from expropriation between generations of voters. Although the evidence in this literature suggests that institutions relating to government accountability and political stability are important for understanding country differences in expropriation risk, we find that these dimensions of institutional quality have relatively modest direct influence on foreign investment decisions once the perceived risk of a 100 per cent loss of assets is accounted for.

Two recent expropriation cases provide clear examples where foreign investors have likely prioritized the return of capital over considerations of ex post asset returns and variability when deciding whether to invest in a particular market. Ecuador introduced a new law in 2007 requiring private oil companies to renegotiate production-sharing contracts and concede a greater proportion of revenues to the government. In 2008, President Rafael Correa's administration announced its intention to convert all foreign productionsharing agreements to service contacts and, in May 2010, foreign firms were given an end-of-year deadline to sign new service contracts. Companies that chose not to comply received the following threat from the president: "With this new law, petroleum companies that do not abide by the policies of the state will have their fields nationalized and

\footnotetext{
${ }^{46} \mathrm{~A}$ number of factors have, in turn, been identified as sources of the relatively acute political instability in Latin America, including income inequality, ethnic tensions, and democratic institutions (see Roberts and Wibbels, 1999; Acemoglu and Robinson, 2001; Blanco and Grier, 2009). See also Svensson (1998) on the relationship between political stability and property rights.
} 
they will leave the country" (Expropriation News, July 30, 2010). ${ }^{47}$ A second example is Venezuela. Recent nationalizations of foreign-owned assets gave that country one of the worst rankings in terms of expropriation risk. Following a wave of cancellations of foreign investor mining and petroleum contracts beginning in 2001, President Hugo Chavez turned his attention to other industries. He ordered an abrupt nationalization of the cement producer, Cemex, on August 19, 2008, and all rice processing and packaging plants were nationalized in an announcement made on February 28, 2009. US energy exploration firm, Helmerich and Payne, had its Venezuelan assets nationalized on June 24, 2010. And two glass manufacturing plants in Venezuela were nationalized on October 25, 2010 (US Department of State, March 2011). ${ }^{48}$

With these recent threats of nationalizations of foreign-owned assets, Ecuador and Venezuela have obtained two of the worst global rankings in terms of expropriation risk. It is interesting to note that, in line with the evidence in Jensen (2008), the chief executives in both countries have sought to consolidate political power during these episodes of heightened expropriation risk. ${ }^{49}$ The responses of foreign investors are striking. FDI inflows to Ecuador had contracted by 25 per cent over 2008-2013 relative to average flows prior to the announced contract renegotiations, and in Venezuela, FDI inflows declined by 60 per cent over 2001-2010 relative to the preceding decade. These examples complement the information revealed by filtering the available panel data through the empirical models compared in this paper, and provide relatively sharp evidence that matches (a nearly obvious) intuition: If a country's institutional quality cannot credibly deliver a high probability of avoiding expropriation, then other institutional differences have little chance to compensate and attract new foreign investments.

\footnotetext{
${ }^{47}$ Retrieved from https://expropriationnewseditor.wordpress.com/2010/07/30/ oil-firms-face-ecuador-asset-grab/.

${ }^{48}$ Retrieved from https://www.state.gov/e/eb/rls/othr/ics/2011/157383.htm.

${ }^{49}$ In Ecuador, a 2007 referendum gave more powers to the constituent assembly, including the ability to dismiss Congress, and the 16 constitutional reforms approved by Ecuador's National Assembly in December 2015 sought to further strengthen political control of the executive, including the removal of consecutive term-limits for the president ("Ecuador's Assembly Approves Constitutional Reform Package," The Wall Street Journal, Dec. 3, 2015). Under Chavez, the 1999 Venezuelan constitutional reforms eliminated several checks and balances and made censorship easier, while the 2009 referendum also removed term-limits on the presidency. These moves to consolidate power were reflected in sharp declines in the Polity IV index of executive constraints (investigated by Jensen) for both countries, dropping from two of the highest scores within Latin America prior to 1998 to the two lowest scores in the region by 2007.
} 


\section{Conclusions}

This paper documents economically and statistically significant effects of expropriation risk on FDI. By the criteria of estimated effect size, statistical significance, and simulated effects of counterfactual ceteris paribus improvements in institutional quality on FDI (holding other dimensions of institutional quality constant), this evidence supports an interpretation that expropriation risk dominates other dimensions of institutional quality (or political risk). Expropriation is an abrupt and total loss of invested principal, whereas other dimensions of institutional quality primarily influence the mean and variance of investment returns conditional on not losing everything. One might therefore expect foreign investors to put more weight on expropriation risk than other institutional variables. Our results bear this expectation out. The data rather clearly differentiate expropriation risk from other dimensions of political risk as influences on FDI. This result stands in stark contrast to the mixed results reported in previous studies. Our findings prompt the question of why expropriation risk has not shown up as the dominant institutional characteristic in previous empirical investigations.

One likely reason is model misspecification of multiple kinds, which we demonstrate both theoretically and empirically. We present a theoretical model of FDI with endogenous expropriation risk and other measures of institutional quality which shows that, when there is a binding threat of expropriation, the other measures of institutional quality have theoretically indeterminate effects on FDI. The intuition is that improved quality on one dimension improves the profitability of the foreign-owned firm, thereby increasing the host government's temptation to expropriate. This intuition goes against the conventional view that improved institutional quality should be positively associated with FDI. Theoretically indeterminate effects of non-expropriation measures of institutional quality on FDI demonstrated by our model help rationalize why, empirically, non-expropriation measures of institutional quality have few economically and statistically significant effects on FDI.

Another finding from our theoretical framework is that inward and outward FDI flows are predicted to respond to institutional characteristics according to markedly different response functions. This finding makes gross rather than net FDI more attractive as a dependent variable because the two gross flows subtracted to arrive at net FDI generally respond to changes in institutional quality in importantly different ways. A measured effect of institutional quality on net FDI combines the differential responses of inflows 
versus outflows to changes in a country's institutions in a way that is impossible to represent by standard log-linear models of FDI. Our preferred empirical models therefore use gross rather than net FDI as the dependent variable.

Finally, numerous empirical studies of FDI include only partial subsets of the available variables measuring institutional quality. Omitting one or more institutional variables that enter the true FDI-data-generating process results in potential bias. Each of the empirical model specifications we consider uses all information contained in the 12 ICRG indices measuring institutional quality. Across numerous alternative specifications and robustness checks, our analysis finds that expropriation risk has a large and statistically significant effect on FDI that dominates all other measures of institutional quality in terms of influence on the expected percentage change in FDI inflows.

FDI is a relatively large proportion of all capital flows to developing countries. Intuition and evidence both suggest that FDI is important for development. FDI can bring improvements in technology and managerial expertise to developing countries, generating substantial direct benefits and economy-wide spillover effects. ${ }^{50}$ Despite these potential benefits, many developing countries attract little or no FDI. Our empirical results corroborate previous findings that host-country institutions are a significant factor in accounting for the large variation in FDI across developing countries. However, our main finding is novel-that expropriation risk appears to dominate other dimensions of institutional quality in influencing FDI flows to developing countries.

This perspective finds additional support in survey data collected by the World Bank's Multilateral Investment Guarantee Agency (MIGA), which suggest that expropriation is the most important factor among a large set of risk factors thought to affect multinational enterprises' choices of location (MIGA-EIU, Political Risk Survey 2011). ${ }^{51}$ Survey respondents' three most worrisome political risks in emerging economies were breaches of contract, sudden regulatory changes, and transfer and convertibility restrictions. ${ }^{52}$ The rising number of expropriations of FDI among developing countries in recent years suggests that this form of political risk is, in all likelihood, a growing real-world concern for foreign investors.

\footnotetext{
${ }^{50}$ Empirical evidence supports the view that FDI contributes to productivity growth in host countries (Borensztein et al., 1998; Li and Liu, 2005).

${ }^{51}$ See MIGA's 2011 report, "World Investment and Political Risk," published online at: https:// WWW. miga.org/documents/WIPR11.pdf.

${ }^{52}$ It is interesting to note that the definition of the ICRG Investment Profile variable used in our empirical analysis as the primary measure of expropriation risk is based on three sub-components corresponding one-for-one to the three risks cited in the MIGA study.
} 


\section{References}

Acemoglu, Daron and James A Robinson (2001). "A Theory of Political Transitions," American Economic Review: 938-963.

Adam, Antonis and Fragkiskos Filippaios (2007). "Foreign Direct Investment and Civil Liberties: A New Perspective," European Journal of Political Economy, 23 (4): 10381052 .

Addison, Tony and Almas Heshmati (2003). "The New Global Determinants of FDI Flows to Developing Countries: The Importance of ICT and Democratization," WIDER Discussion Papers, World Institute for Development Economics (UNU-WIDER), 45.

Aguiar, Mark, Manuel Amador, and Gita Gopinath (2009). "Expropriation Dynamics," American Economic Review: Papers and Proceedings, 99 (2): 473-479.

Albuquerque, Rui (2003). “The Composition of International Capital Flows: Risk Sharing through Foreign Direct Investment," Journal of International Economics, 61 (2): 353-383.

Albuquerque, Rui, Norman Loayza, and Luis Servén (2005). "World Market Integration Through the Lens of Foreign Direct Investors," Journal of International Economics, 66 (2): 267-295.

Alfaro, Laura, Sebnem Kalemli-Ozcan, and Vadym Volosovych (2008). "Why Doesn't Capital Flow from Rich to Poor Countries? An Empirical Investigation," The Review of Economics and Statistics, 90 (2): 347-368.

Ali, Fathi A., Norbert Fiess, and Ronald MacDonald (2010). "Do Institutions Matter for Foreign Direct Investment?” Open Economies Review, 21 (2): 201-219.

Arellano, Manuel and Stephen Bond (1991). "Some Tests of Specification for Panel Data: Monte Carlo Evidence and an Application to Employment Equations," The Review of Economic Studies, 58 (2): 277-297.

Arezki, Rabah and Markus Brückner (2011). "Oil Rents, Corruption, and State Stability: Evidence from Panel Data Regressions," European Economic Review, 55 (7): 955-963.

Asiedu, Elizabeth (2002). "On the Determinants of Foreign Direct Investment to Developing Countries: Is Africa Different?” World Development, 30 (1): 107-119.

(2006). "Foreign Direct Investment in Africa: The role of Natural Resources, Market Size, Government Policy, Institutions and Political Instability," The World Economy, 29 (1): 63-77. 
Asiedu, Elizabeth, Yi Jin, and Boaz Nandwa (2009). "Does Foreign Aid Mitigate the Adverse Effect of Expropriation Risk on Foreign Direct Investment?" Journal of International Economics, 78 (2): 268-275.

Asiedu, Elizabeth and Donald Lien (2011). "Democracy, Foreign Direct Investment and Natural Resources," Journal of International Economics, 84 (1): 99-111.

Azzimonti, Marina and Pierre-Daniel Sarte (2007). "Barriers to Foreign Direct Investment Under Political Instability," Economic Quarterly - Federal Reserve Bank of Richmond, 93 (3): 287.

Bellak, Christian (1998). "The Measurement of Foreign Direct Investment: A Critical Review," The International Trade Journal, 12 (2): 227-257.

Bellak, Christian and Markus Leibrecht (2009). "Do Low Corporate Income Tax Rates Attract FDI? Evidence from Central and East European Countries," Applied Economics, 41 (21): 2691-2703.

Bénassy-Quéré, Agnès, Maylis Coupet, and Thierry Mayer (2007). "Institutional Determinants of Foreign Direct Investment," The World Economy, 30 (5): 764-782.

Berg, Nathan (2014a). "Success from Satisficing and Imitation: Entrepreneurs' Location Choice and Implications of Heuristics for Local Economic Development," Journal of Business Research, 67 (8): 1700-1709.

(2014b). "The Consistency and Ecological Rationality Schools of Normative Economics: Singular versus Plural Metrics for Assessing Bounded Rationality,' Journal of Economic Methodology, 21 (4): 375-395.

Berg, Nathan and Gerd Gigerenzer (2007). "Psychology Implies Paternalism? Bounded Rationality May Reduce the Rationale to Regulate Risk-Taking," Social Choice and Welfare, 28 (2): 337-359.

Beugelsdijk, Sjoerd, Jean-François Hennart, Arjen Slangen, and Roger Smeets (2010). "Why and How FDI Stocks are a Biased Measure of MNE Affiliate Activity," Journal of International Business Studies, 41 (9): 1444-1459.

Biswas, Romita (2002). "Determinants of Foreign Direct Investment," Review of Development Economics, 6 (3): 492-504.

Blanco, Luisa and Robin Grier (2009). "Long Live Democracy: The Determinants of Political Instability in Latin America," Journal of Development Studies, 45 (1): 76-95.

Blundell, Richard and Stephen Bond (1998). "Initial Conditions and Moment restrictions in Dynamic Panel Data Models," Journal of Econometrics, 87 (1): 115-143. 
Borensztein, Eduardo, Jose De Gregorio, and Jong-Wha Lee (1998). "How Does Foreign Direct Investment Affect Economic Growth?" Journal of International Economics, 45 (1): 115-135.

Burbidge, John B., Lonnie Magee, and Leslie A. Robb (1988). "Alternative Transformations to Handle Extreme Values of the Dependent Variable," Journal of the American Statistical Association, 83 (401): 123-127.

Busse, Matthias (2004). "Transnational Corporations and Repression of Political Rights and Civil Liberties: An Empirical Analysis," Kyklos, 57 (1): 45-65.

Busse, Matthias and Carsten Hefeker (2007). "Political Risk, Institutions and Foreign Direct Investment,” European Journal of Political Economy, 23 (2): 397-415.

Caddel, Jeremy and Nathan M. Jensen (2014). "Which Host-Country Government Actors are Most Involved in Disputes with Foreign Investors?" Columbia FDI Perspectives (120).

Chakrabarti, Avik (2001). "The Determinants of Foreign Direct Investments: Sensitivity Analyses of Cross-Country Regressions," Kyklos, 54 (1): 89-114.

Cole, Harold L. and William B. English (1991). "Expropriation and Direct Investment," Journal of International Economics, 30 (3-4): 201-227.

Colen, Liesbeth, Damiaan Persyn, and Andrea Guariso (2016). "Bilateral Investment Treaties and FDI: Does the Sector Matter?" World Development, 83: 193-206.

Daude, Christian and Ernesto Stein (2007). "The Quality of Institutions and Foreign Direct Investment," Economics \& Politics, 19 (3): 317-344.

Eaton, Jonathan and Mark Gersovitz (1984). "A Theory of Expropriation and Deviations from Perfect Capital Mobility," The Economic Journal, 94: 16-40.

Edwards, Sebastian (1992). "Capital Flows, Foreign Direct Investment, and Debt-Equity Swaps in Developing Countries," NBER Working Paper No. 3497.

Egger, Peter and Hannes Winner (2005). "Evidence on Corruption as an Incentive for Foreign Direct Investment," European Journal of Political Economy, 213 (2): 932952.

Faria, Andre and Paolo Mauro (2009). "Institutions and the External Capital Structure of Countries," Journal of International Money and Finance, 28 (3): 367-391.

Fratzscher, Marcel and Jean Imbs (2009). "Risk Sharing, Finance, and Institutions in International Portfolios,” Journal of Financial Economics, 94 (3): 428-447. 
Gastanaga, Victor M., Jeffrey B. Nugent, and Bistra Pashamova (1998). "Host Country Reforms and FDI Inflows: How Much Difference Do They Make?" World Development, 26 (7): 1299-1314.

Gigerenzer, Gerd and Daniel G. Goldstein (1996). "Reasoning the Fast and Frugal Way: Models of Bounded Rationality," Psychological Review, 103 (4): 650-669.

Globerman, Steven and Daniel Shapiro (2002). “Global Foreign Direct Investment Flows: the Role of Governance Infrastructure,” World Development, 30 (11): 1899-1919.

Guggenberger, Patrik (2010). "The impact of a hausman pretest on the size of a hypothesis test: The panel data case," Journal of Econometrics, 156 (2): 337-343.

Guriev, Sergei, Anton Kolotilin, and Konstantin Sonin (2011). "Determinants of Nationalization in the Oil Sector: A Theory and Evidence from Panel Data," Journal of Law, Economics, and Organization, 27 (2): 301-323.

Habib, Mohsin and Leon Zurawicki (2002). "Corruption and Foreign Direct Investment," Journal of international business studies, 33 (2): 291-307.

Hajzler, Christopher (2012). "Expropriation of Foreign Direct Investments: Sectoral Patterns from 1993 to 2006," Review of World Economics/Weltwirtschaftliches Archiv., 148 (1): 119-149.

(2014). "Resource-based FDI and Expropriation in Developing Economies," Journal of International Economics, 92 (1): 124-146.

Hajzler, Christopher and Jonathan Rosborough (2016). "Government Corruption and Foreign Direct Investment Under the Threat of Expropriation," Bank of Canada Staff Working Paper 2016-13: 1-12.

Hakkala, Katariina Nilsson, Pehr-Johan Norbäck, and Helena Svaleryd (2008). "Asymmetric Effects of Corruption on FDI: Evidence from Swedish Multinational Firms," The Review of Economics and Statistics, 90 (4): 627-642.

Harms, Philipp (2002). "Political Risk and Equity Investment in Developing Countries," Applied Economics Letters, 9 (6): 377-380.

Harms, Philipp and Philipp an de Meulen (2013). "Demographic Structure and the Security of Property Rights: The Role of Development and Democracy," European Journal of Political Economy, 29: 73-89.

Harms, Philipp and Heinrich W. Ursprung (2002). "Do Civil and Political Repression Really Boost Foreign Direct Investments?” Economic Inquiry, 40 (4): 651-663. 
Helpman, Elhanan, Marc Melitz, and Yona Rubinstein (2008). "Estimating Trade Flows: Trading Partners and Trading Volumes," The Quarterly Journal of Economics, 123 (2): 441-487.

Jensen, Nathan M. (2003). "Democratic Governance and Multinational Corporations: Political Regimes and Inflows of Foreign Direct Investment," International Organization, 57 (3): 587-616.

(2008). "Political Risk, Democratic Institutions, and Foreign Direct Investment," The Journal of Politics, 70 (04): 1040-1052.

Karl, Joachim (2013). "Investor-State Dispute Settlement: A Government's Dilemma," Columbia FDI Perspectives (89).

Kerner, Andrew (2014). "What We Talk About When We Talk About Foreign Direct Investment," International Studies Quarterly, 58 (4): 804-815.

Kinoshita, Yuko and Nauro Campos (2003). "Why Does FDI Go Where it Goes? New Evidence from the Transition Countries," William Davidson Institute Working Paper, 573.

Kobrin, Stephen J. (1984). "Expropriation as an Attempt to Control Foreign Firms in LDCs: Trends from 1960 to 1979," International Studies Quarterly, 28 (3): 329-348.

Koessler, Frédéric and Ariane Lambert-Mogiliansky (2014). "Extortion and PoliticalRisk Insurance," Journal of Public Economics, 120: 144-156.

Kolstad, Ivar and Line Tøndel (2002). "Social Development and Foreign Direct Investments in Developing Countries," Chr. Michelsen Institute Working Paper.

Kolstad, Ivar and Espen Villanger (2008). "Determinants of Foreign Direct Investment in Services," European Journal of Political Economy, 24 (2): 518-533.

Li, Quan (2009). "Democracy, Autocracy, and Expropriation of Foreign Direct Investment," Comparative Political Studies, 42 (8): 1098-1127.

Li, Quan and Adam Resnick (2003). "Reversal of Fortunes: Democratic Institutions and Foreign Direct Investment Inflows to Developing Countries," International Organization, 57 (01): 175-211.

Li, Xiaoying and Xiaming Liu (2005). "Foreign Direct Investment and Economic Growth: an Increasingly Endogenous Relationship,” World Development, 33 (3): 393-407.

Linders, Gert-Jan M. and Henri L.F. de Groot (2014). "Estimation of the Gravity Equation in the Presence of Zero Flows," Econometrica, 82 (2): 705-30. 
Lipsey, Robert E. (2007). "Defining and Measuring the Location of FDI Output," NBER Working Paper No. 12996.

Lucas, Robert E (1990). "Why Doesn't Capital Flow from Rich to Poor Countries?" The American Economic Review, 80 (2): 92-96.

Mathur, Aparna and Kartikeya Singh (2013). "Foreign Direct Investment, Corruption and Democracy," Applied Economics, 45 (8): 991-1002.

Méon, Pierre-Guillaume and Khalid Sekkat (2004). "Does the Quality of Institutions Limit the MENA's Integration in the World Economy?" The World Economy, 27 (9): 1475-1498.

Naudé, W.A. and W.F. Krugell (2007). "Investigating Geography and Institutions as Determinants of Foreign Direct Investment in Africa Using Panel Data," Applied Economics, 39 (10): 1223-1233.

Noorbakhsh, Farhad, Alberto Paloni, and Ali Youssef (2001). "Human Capital and FDI Inflows to Developing Countries: New Empirical Evidence," World Development, 29 (9): 1593-1610.

Okada, Keisuke (2013). "The interaction effects of financial openness and institutions on international capital flows," Journal of Macroeconomics, 35: 131-143.

Opp, Marcus M. (2012). “Expropriation Risk and Technology,” Journal of Financial Economics, 103 (1): 113-129.

Papaioannou, Elias (2009). "What Drives International Financial Flows? Politics, Institutions and Other Determinants," Journal of Development Economics, 88 (2): 269-281.

Phelan, Christopher (2006). "Public Trust and Government Betrayal," Journal of Economic Theory, 130 (1): 27-43.

Reinhardt, Dennis, Luca Antonio Ricci, and Thierry Tressel (2013). "International Capital Flows and Development: Financial Openness Matters," Journal of International Economics, 91 (2): 235-251.

Roberts, Kenneth M and Erik Wibbels (1999). "Party Systems and Electoral Volatility in Latin America: A Test of Economic, Institutional,and Structural Explanations," American Political Science Review: 575-590.

Root, Franklin R. and Ahmed A. Ahmed (1979). "Empirical Determinants of Manufacturing Direct Foreign Investment in Developing Countries," Economic Development and Cultural Change: 751-767. 
Sánchez-Martin, Miguel Eduardo, Rafael De Arce, and Gonzalo Escribano (2014). "Do Changes in the Rules of the Game Affect FDI Flows in Latin America? A Look at the Macroeconomic, Institutional and Regional Integration Determinants of FDI," European Journal of Political Economy, 34: 279-299.

Schneider, Friedrich and Bruno S. Frey (1985). "Economic and Political Determinants of Foreign Direct Investment," World Development, 13 (2): 161-175.

Stroebel, Johannes and Arthur Van Benthem (2013). "Resource Extraction Contracts under Threat of Expropriation: Theory and Evidence," Review of Economics and Statistics, 95 (5): 1622-1639.

Svensson, Jakob (1998). "Investment, property rights and political instability: Theory and evidence," European Economic Review, 42 (7): 1317-1341.

Thomas, Jonathan and Thomas Worrall (1994). "Foreign direct Investment and the Risk of Expropriation," The Review of Economic Studies, 61 (1): 81-108.

Tomz, Michael and Mark Wright (2010). "Sovereign Theft: Theory and Evidence about Sovereign Default and Expropriation," in William Hogan and Federico Sturzenegger eds. The Natural Resources Trap: Private Investment without Public Commitment, Cambridge, MA: MIT Press: 69-110.

Wei, Shang Jin (2000). "How Taxing is Corruption on International Investors?" Review of Economics and Statistics, 82 (1): 1-11.

Wheeler, David and Ashoka Mody (1992). "International Investment Location Decisions: The Case of US Firms,” Journal of International Economics, 33 (1): 57-76.

Wisniewski, Tomasz P. and Saima K. Pathan (2014). "Political Environment and Foreign Direct Investment: Evidence from OECD Countries," European Journal of Political Economy, 36: 13-23.

Yang, Benhua (2007). "Autocracy, Democracy, and FDI Inflows to the Developing Countries," International Economic Journal, 21 (3): 419-439. 


\section{Appendix A: Empirical Literature on Expropriation Risk and Risk Indicators Used}

\begin{tabular}{|c|c|c|c|}
\hline Article & Sample & Expropriation Risk Measure / Instrument & Other Institutional Quality / Risk Measures \\
\hline $\begin{array}{l}\text { Adam and Filippaios } \\
\text { (2007) }\end{array}$ & 105 countries $(1989-1997)$ & $\begin{array}{l}\text { Investment Profile (ICRG: International } \\
\text { Country Risk Guide) }\end{array}$ & $\begin{array}{l}\text { Corruption and Bureaucratic Quality (ICRG); Political } \\
\text { and Civil Liberties (Freedom House) }\end{array}$ \\
\hline Ali et al. (2010) & $\begin{array}{l}69 \text { developing countries } \\
(1981-2005)\end{array}$ & $\begin{array}{l}\text { Sum of Investment Profile and Law and } \\
\text { Order (ICRG) }\end{array}$ & Taxation (top marginal corporate tax rate) \\
\hline Aguiar et al. (2009) & Argentina (1984-2007) & Investment Profile (ICRG) & $\begin{array}{l}\text { Overall political risk (inverse of ICRG aggregate } \\
\text { index) }\end{array}$ \\
\hline Asiedu (2002) & $\begin{array}{l}71 \text { developing countries } \\
(1988-1997)\end{array}$ & Political Instability (Barro and Lee, 1993) & Taxation (Government consumption, share of GDP) \\
\hline Asiedu et al. (2009) & $\begin{array}{l}63 \text { developing countries } \\
(1983-2004)\end{array}$ & Investment Profile (ICRG) & None \\
\hline $\begin{array}{l}\text { Asiedu and Lien } \\
\text { (2011) }\end{array}$ & $\begin{array}{l}87 \text { developing countries } \\
(1982-2007)\end{array}$ & Investment Profile (ICRG) & $\begin{array}{l}\text { Democracy (Freedom House, Polity IV, ICRG); Cor- } \\
\text { ruption, Rule of Law, and Bureaucratic quality (ICRG) }\end{array}$ \\
\hline $\begin{array}{l}\text { Bénassy-Quéré et al. } \\
\text { (2007) }\end{array}$ & $\begin{array}{l}52 \text { origin and destination } \\
\text { countries (bilateral FDI } \\
\text { stocks) }(1985-2000)\end{array}$ & $\begin{array}{l}\text { Contract law and Property rights protec- } \\
\text { tion (French Ministry) }\end{array}$ & $\begin{array}{l}\text { Remaining } 75 \text { standardized institutional indices } \\
\text { (French Ministry); Credit market regulation (Fraser } \\
\text { Institute) }\end{array}$ \\
\hline Biswas (2002) & $\begin{array}{l}44 \text { developed and } \\
\text { developing countries } \\
(1983-1990)\end{array}$ & $\begin{array}{l}\text { Sum of Expropriation Risk, Contract Re- } \\
\text { pudiation, Corruption, Quality of Bu- } \\
\text { reacracy, and Law and Order (ICRG) }\end{array}$ & $\begin{array}{l}\text { Regime type and Regime duration (Center for Institu- } \\
\text { tional Reforms and the Informal Sector) }\end{array}$ \\
\hline $\begin{array}{l}\text { Busse and Hefeker } \\
\text { (2007) }\end{array}$ & 83 countries $(1984-2000)$ & Investment Profile (ICRG) & Remaining 11 ICRG indices \\
\hline $\begin{array}{l}\text { Daude and Stein } \\
(2007)\end{array}$ & $\begin{array}{l}152 \text { destination countries } 34 \\
\text { origin countries (bilateral } \\
\text { FDI) }(1982-2002)\end{array}$ & $\begin{array}{l}\text { Investment Profile (ICRG); Government } \\
\text { Effectiveness (sum of Quality of Bu- } \\
\text { reaucracy, Competence of Civil Servants, } \\
\text { Quality of Public Service, and Credibil- } \\
\text { ity of Government Policy, from WGI: } \\
\text { Worldwide Governance Indicators) }\end{array}$ & $\begin{array}{l}\text { Voice and Accountability, Political Stability and Lack } \\
\text { of Violence, Regulatory Quality, Rule of Law, and } \\
\text { Corruption (WGI); Government Stability, Corrup- } \\
\text { tion, Democratic Accountability, and Law and Order } \\
\text { (ICRG) }\end{array}$ \\
\hline $\begin{array}{l}\text { Fratzscher and Imbs } \\
(2009)\end{array}$ & $\begin{array}{l}54 \text { destination and origin } \\
\text { countries (bilateral stocks) } \\
(1999-2003)\end{array}$ & $\begin{array}{l}\text { Contract enforcement (La Porta et al., } \\
\text { 1998); Investment Profile (ICRG) }\end{array}$ & Corruption (WGI) \\
\hline
\end{tabular}




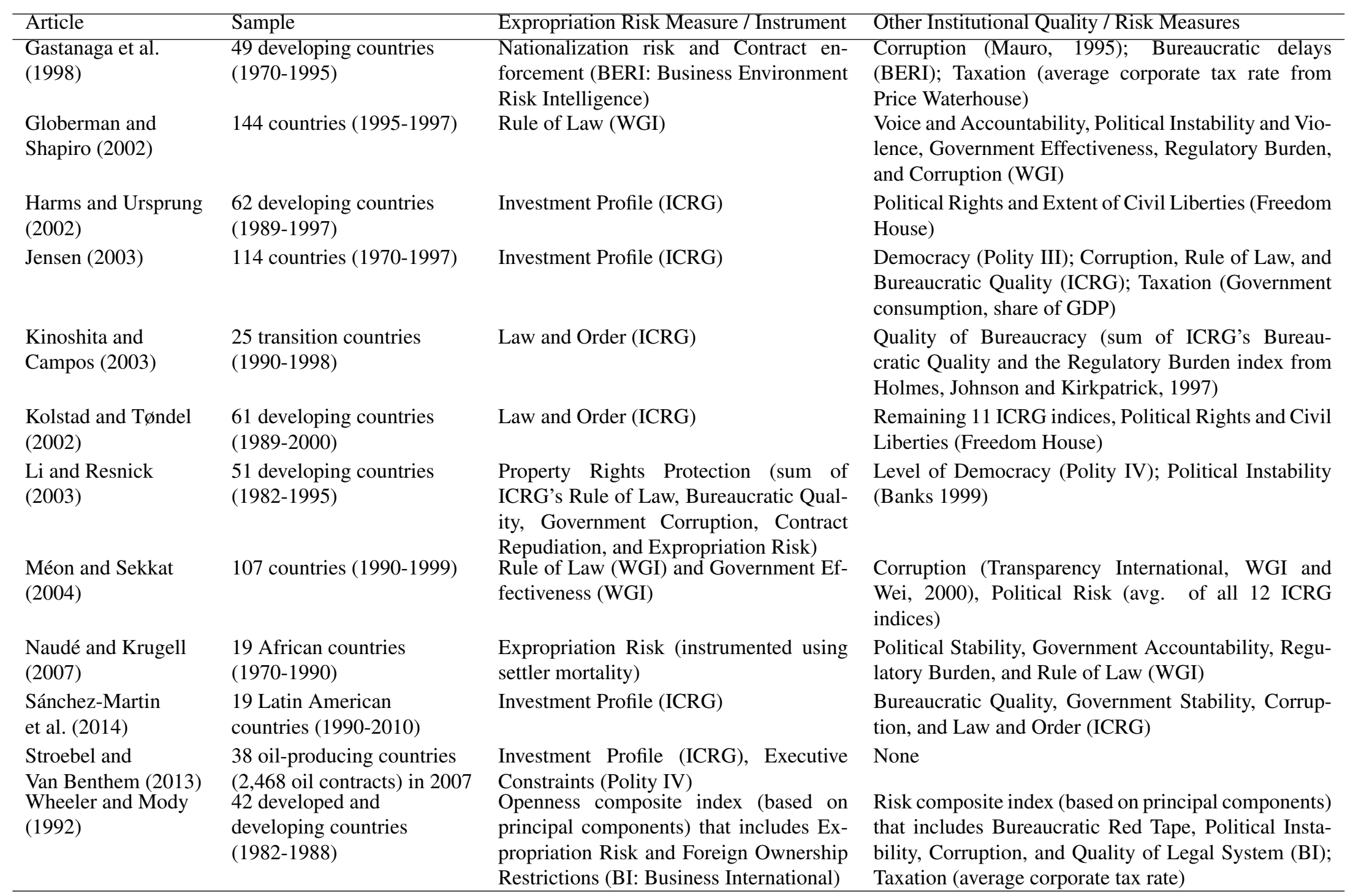




\section{Appendix B: Data Sources, Variables, and Construction of Measures of Institutional Quality}

The following section provides a brief description of the indices that we use as measures of institutional quality or, synonymously, as political risk variables. The ICRG provides 12 indices of political risks: Government Stability (12-point scale), Socioeconomic Tensions (12-point scale), Investment Profile (12-point scale), Internal Conflict (12-point scale), External Conflict (12-point scale), Corruption (6 points), Military in Politics (6 points), Religion in Politics (6 points), Law and Order (6 points), Ethnic Tensions (6 points), Democratic Accountability (6 points), and Bureaucratic Quality (4 points).

Government Stability captures the government's ability to carry out its declared programs. Annual rating range is from 0 to 12 . Socioeconomic Tensions refers to the socioeconomic pressure at work in society that can create social dissatisfaction and restrain government actions. It is the sum of three subcomponents (unemployment, consumer confidence, and poverty), which each range from 0 to 4 . Investment Profile is an assessment of factors affecting the risks of investment that are not directly covered by other political, economic and financial risk components. It is the sum of three subcomponents (expropriation risk, payment delays and restrictions on profit repatriation), once again ranging from 0 to 4 .

Internal Conflict refers to political violence in the country and its actual or potential impact on governance. A higher score indicates lower conflict, and the average yearly rating is from 0 to 12. External Conflict is an assessment of the risk of the incumbent government from foreign hostile action, ranging from non-violent external pressure (diplomatic pressures, withholding of aid, trade restrictions, territorial disputes, sanctions, etc.) to violent external pressure (from cross-border conflicts to all-out war). The subcomponents are war, cross-border conflict, and foreign pressure, each with a maximum score of 4 and a minimum score of 0 . Corruption assesses the corruption within the political system. Such corruption can pose a significant threat to foreign investment as a common form of corruption met by business is in the form of demands for special payments, bribes etc. The average yearly rating is from 0 to 6. Military in Politics captures the perceptions of the extent to which the military becomes involved in politics or constrains government action (including use of military force on the elected government to influence policy or to force a replacement of the incumbent government), and scores range from 0 to 6 . Religious Tensions may stem from the domination of society and government by a single religious group that seeks to replace civil law by religious law and suppress religious freedom; the average yearly rating ranges from 0 to 6. Law and Order is an assessment of the strength and impartiality of the legal system and of popular observance of the law, ranging from 0 to 6. Ethnic Tensions assess the degree of ethnic tensions within a country attributable to racial, nationality, or language divisions; the average yearly rating is from 0 to 6 . Democratic Accountability assesses how responsive government is to its people, ranging from 0 (authoritarian regimes) to 6 (alternating democracies). Finally, Bureaucratic Quality measures the strength and quality of the bureaucracy as another shock absorber that tends 
to minimize revisions of policy when the ruling government changes. The average yearly rating is from 0 to 4 .

To ensure the consistency of interpretation of estimated regression coefficients, each sub-component of the ICRG index is rescaled from 0 to 10 , where scales are defined so that higher scores in all cases indicate higher quality institutions (i.e., higher scores indicate lower levels of political risk).

It is important to acknowledge that the definition of ICRG's Investment Profile, which aims to capture the sum of Contract Viability/Expropriation, Restrictions on Profits Repatriation, and the Likelihood of Payment Delays, includes some components that are not directly tied to expropriation risk. Therefore, there is some component in even the narrowest ICRG proxy for expropriation that does not capture expropriation per se. In the other direction, there are expropriation events that fit definitions captured by other ICRG indices such as law and order and government stability, which has motivated some authors to construct composite measures that they argue better correspond to real-world risk of expropriation. The implication is that the match between ICRG indices and real-world expropriation risk is imperfect, and this imperfection reflects misses in both directions, which has motivated researchers to use various combinations of information in the ICRG indices to measure expropriation risk. The narrowest is the ICRG Investment Profile, referred to in our paper as ICRG Expropriation Risk. While we acknowledge the imperfect correspondence between the ICRG proxy and real-world expropriation risk, we believe (as other scholars have also argued) that the case can be made that broader composite measures of expropriation risk may better correspond to real-world expropriation risk, and that other ICRG risk components may be tied to expropriation events, such as ICRG Law and Order and Government Stability. The composite measures of Expropriation Risk Absent defined in Table 1 span a range from the narrowest definition (Taxonomy 2 ) to the broadest (Taxonomy 4). Arguments can be made in favor of any of these, depending on the loss function one has in mind concerning likely instances of over- and under-counting using any one of these imperfect measures. 
Table B1: Macroeconomic Variables and Data Sources

\begin{tabular}{|c|c|c|}
\hline Variable & Definition & Source \\
\hline Net FDI per capita & $\begin{array}{l}\text { FDI inflows minus FDI outflows } \\
\text { per capita (US dollars at } \\
\text { current prices and exchange rates) }\end{array}$ & UNCTAD (2016) \\
\hline Gross FDI inflows & $\begin{array}{l}\text { FDI inflows net of profit repatriation } \\
\text { and other disinvestments } \\
\text { (current US dollars) }\end{array}$ & UNCTAD (2016) \\
\hline $\begin{array}{l}\text { Gross FDI inflows } \\
\text { per capita }\end{array}$ & $\begin{array}{l}\text { Gross FDI inflows divided by } \\
\text { total population } \\
\text { (current US dollars) }\end{array}$ & UNCTAD (2016) \\
\hline $\begin{array}{l}\text { Government } \\
\text { Consumption }\end{array}$ & $\begin{array}{l}\text { Government consumption } \\
\text { (Share of GNI) }\end{array}$ & WDI, World Bank (2016) \\
\hline GNI & $\begin{array}{l}\text { Gross National Income, } \\
\text { PPP (current international dollars) }\end{array}$ & WDI, World Bank (2016) \\
\hline GNI per capita & $\begin{array}{l}\text { Gross National Income per capita, } \\
\text { PPP (current international dollars) }\end{array}$ & WDI, World Bank (2016) \\
\hline $\begin{array}{l}\text { GNI per capita } \\
\text { growth }\end{array}$ & $\begin{array}{l}\text { Gross National Income per capita } \\
\text { growth (annual \%) }\end{array}$ & WDI, World Bank (2016) \\
\hline Inflation & GDP deflator (annual \%) & WDI, World Bank (2016) \\
\hline Trade & $\begin{array}{l}\text { Sum of exports and imports } \\
\text { (\% of GDP) }\end{array}$ & WDI, World Bank (2016) \\
\hline
\end{tabular}


Table B2: The 83 Country Sample

Albania (ALB), Algeria (DZA), Angola (AGO), Argentina (ARG), Bangladesh (BGD), Bolivia (BOL), Botswana (BWA), Brazil (BRA), Bulgaria (BGR), Burkina Faso (BFA), Cameroon (CMR), Chile (CHL), China (CHN), Colombia (COL), Congo, Democratic Republic (ZAR), Congo Republic (COG), Costa Rica (CRI), Cote d'Ivoire (CIV), Czech Republic (CZE), Dominican Republic (DOM), Ecuador (ECU), Egypt (EGY), El Salvador (SLV), Ethiopia (ETH), Gabon (GAB), Gambia (GMB), Ghana (GHA), Guatemala (GTM), Guinea (GIN), Guinea-Bissau (GNB), Guyana (GUY), Haiti (HTI), Honduras (HND), Hungary (HUN), India (IND), Indonesia (IDN), Iran (IRN), Jamaica (JAM), Jordan (JOR), Kenya (KEN), South Korea (KOR), Lebanon (LBN), Madagascar (MDG), Malawi (MWI), Malaysia (MYS), Mali (MLI), Mexico (MEX), Mongolia (MNG), Morocco (MAR), Namibia (NAM), Nicaragua (NIC), Niger (NER), Nigeria (NGA), Oman (OMN), Pakistan (PAK), Panama (PAN), Papua New Guinea (PNG), Paraguay (PRY), Peru (PER), Philippines (PHL), Poland (POL), Romania (ROM), Russia (RUS), Saudi Arabia (KSA), Senegal (SEN), Sierra Leone (SLE), Slovakia (SLV), South Africa (ZAF), Sri Lanka (LKA), Sudan (SDN), Syria (SYR), Tanzania (TZA), Thailand (THA), Togo (TGO), Trinidad and Tobago (TTO), Tunisia (TUN), Turkey (TUR), Uganda (UGA), Uruguay (URY), Venezuela (VEN), Vietnam (VNM), Zambia (ZMB), Zimbabwe (ZWE). 


\section{Appendix C: Proof of Results 4.1 and 4.2}

\section{Result 4.1}

Proof. When the threat of expropriation binds $\left(z^{*}(k)<\bar{z}\right)$, fully differentiating (5) with respect to $\tau$ and $k^{*}$ yields

$$
\frac{\partial k^{*}}{\partial \tau}=\frac{-\left(\int_{\underline{z}}^{z^{*}\left(k^{*}\right)} z d \Gamma(z)\right)+\left(z^{*}\left(k^{*}\right)\right)^{2} \cdot \gamma\left(z^{*}\left(k^{*}\right)\right)}{\frac{f_{k}\left(k^{*}\right)}{f\left(k^{*}\right)} \cdot\left(z^{*}\left(k^{*}\right)\right)^{2} \cdot \gamma\left(z^{*}\left(k^{*}\right)\right)-\frac{f_{k k}\left(k^{*}\right)}{f_{k}\left(k^{*}\right)} \cdot\left(\int_{\underline{z}}^{z^{*}\left(k^{*}\right)} z d \Gamma(z)\right)},
$$

where concavity of $f(\cdot)$ and $\gamma(\cdot)>0$ imply that the denominator of this expressin is strictly positive. Evidently, the complete expression may be either positive or negative, depending on the shape of the distribution $\Gamma$ and the constrained-optimal level of investment $k^{*}$. In particular, as $z^{*}\left(k^{*}\right)$ becomes sufficiently small, the numerator of this expression may become positive, povided $\gamma\left(z^{*}\left(k^{*}\right)\right)$ is sufficiently positive.

\section{Result 4.2}

Proof. The relationship between $k^{*}$ and $\alpha$ is given by

$$
\frac{\partial k^{*}}{\partial \alpha}=\frac{\frac{d}{d \alpha}\left(\int_{\underline{z}}^{z^{*}\left(k^{*}\right)} z \gamma(z, \alpha) d z\right)}{f_{k}\left(k^{*}\right) \cdot\left(z^{*}\left(k^{*}\right)\right)^{2} \cdot \gamma\left(z^{*}\left(k^{*}\right)\right)-\frac{f_{k k}\left(k^{*}\right) f\left(k^{*}\right)}{f_{k}\left(k^{*}\right)} \cdot\left(\int_{\underline{z}}^{z^{*}\left(k^{*}\right)} z d \Gamma(z)\right)} .
$$

A positive value for this expression would indicate that the constrained-optimal investment level $k^{*}$ is also increasing with improvements in expected productivity. We do not prove general result for the determination of the sign of (C.1) (which corresponds to the sign of the numerator), but we illustrate the ambiguity in the direction of this relationship based on a series of examples of $\Gamma(z)$.

For the first example, suppose $z$ is uniformly distributed over $[\underline{z}, \bar{z}]$, corresponding to the cdf

$$
\Gamma(z)=\frac{z-\underline{z}}{\bar{z}-\underline{z}}
$$

A first-order stochastic-dominant improvement in this distribution can be modelled in two ways: first, by fixing $s=\bar{z}-\underline{z}$ and increasing $\underline{z}$ and $\bar{z}$ equally by $\alpha>0$; or, second, by fixing $\underline{z}$ and increasing $\bar{z}$ by $\alpha>0$ (equivalently, increasing $s$ by $\alpha$ ). In the first case, it is straightforward to show that the numerator of (C.1) is equal to

$$
\frac{d}{d \alpha}\left(\int_{\underline{z}+\alpha}^{z^{*}\left(k^{*}\right)} \frac{z}{s} d z\right)=-\frac{\underline{z}+\alpha}{s}<0 .
$$


In the second case, the numerator equals

$$
\frac{d}{d \alpha}\left(\int_{\underline{z}}^{z^{*}\left(k^{*}\right)} \frac{z}{s+\alpha} d z\right)=-\frac{1}{(s+\alpha)^{2}}\left(\int_{\underline{z}}^{z^{*}\left(k^{*}\right)} z d z\right)<0 .
$$

Therefore, when $z$ is uniformly distributed, optimal investment is strictly increasing in expected productivity only when the threat of expropriation is non-binding, but is strictly decreasing when the threat of expropriation is binding (over the range of strictly positive foreign investment levels).

As another example, consider the case where realizations of $z$ follow a Weibull distribution:

$$
\gamma(z, \alpha)= \begin{cases}\frac{\lambda}{\alpha^{\lambda}} z^{\lambda-1} e^{-\left(\frac{z}{\alpha}\right)^{\lambda}} & \text { if } z \geq 0 \\ 0 & \text { if } z<0\end{cases}
$$

where $\lambda>0$ is the shape parameter and $\alpha>0$ is a scale parameter. $\alpha$ is also a sufficient statistic for first-order stochastic dominance, with a higher value of $\alpha$ associated with a higher unconditional mean. ${ }^{53}$ In this case, the numerator of (C.1) equals

$$
\frac{\lambda^{2}}{\alpha^{\lambda+1}}\left(\int_{\underline{z}}^{z^{*}\left(k^{*}\right)} z^{\lambda}\left(\left(\frac{z}{\alpha}\right)^{\lambda}-1\right) e^{-\left(\frac{z}{\alpha}\right)^{\lambda}} d z\right) .
$$

Evidently, the integrand of this expression is negative when $z<\alpha$. This implies that if the upper limit of the integral is sufficiently low (i.e., if $c$ is low), provided there is positive foreign investment, $k^{*}$ decreasing in $\alpha$; that is, the constrained optimal investment level increases when there is higher risk of government inefficiency or regulation.

\section{Appendix D: Potential Bias When Net FDI Flows Are Used as the Dependent Variable}

To illustrate the likely bias that results from adopting a linear or log-linear statistical model to estimate the relationship between domestic institutions and net FDI flows, consider the simple model of gross FDI presented in Section 4. Suppose for simplicity that equilibrium relationship between optimal foreign investment per worker $\left(k^{*}\right)$ and the average security of foreign investor property rights $\left(z^{*}\right)$ summarized by condition (5) can be approximated compactly by the following explicit functional forms:

$$
\left(e^{\beta \cdot z^{*}}\right)(1-\tau) \alpha\left(k^{*}\right)^{\alpha-1}=1+r
$$

where $\alpha \in(0,1)$ represents the capital income share of a simple Cobb-Douglas technology and $\beta>0$ captures the positive empirical relationship between foreign property rights security and expected investor returns. Using subscripts $d$ (domestic) and $f$ (for-

\footnotetext{
${ }^{53}$ The unconditional mean is $\alpha \Gamma\left(1+\frac{1}{\lambda}\right)$ where $\Gamma(\cdot)$ represents the standard gamma function.
} 
eign) to track the direction of flows, gross FDI inflows per worker into the domestic economy can be expressed as

$$
k_{d}^{*}=\left(\frac{\left(1-\tau_{d}\right)}{\alpha(1+r)}\right)^{\frac{1}{1-\alpha}} e^{\frac{\beta_{d}}{1-\alpha} z_{d}^{*}}
$$

while FDI outflows per worker are assumed to be analogously defined:

$$
k_{f}^{*}=\left(\frac{\left(1-\tau_{f}\right)}{\alpha(1+r)}\right)^{\frac{1}{1-\alpha}} e^{\frac{\beta_{f}}{1-\alpha} z_{f}^{*}}
$$

Here $\tau_{f}$ and $z_{f}^{*}$ should be interpreted as the average sales/revenue taxes and property rights security that domestic investors face when investing overseas.

Taking the natural log of both sides of (D.1) and (D.2) yields (by construction) simple, log-linear relationships between gross FDI inflows/outflows and the political risk index of the respective host country: $\partial \ln k_{j}^{*} / \partial z_{j}^{*}=\beta_{j}(j=\{d, f\})$. However, this does not imply a simple log-linear relationship between net inflows and political risk. On the contrary, our simple model suggests that the marginal effect of an increase in $z_{d}^{*}$ on net inflows will depend on the magnitudes of both net inflows and gross outflows.

Consider the natural log of net inflows per person, $\ln \left(k^{n e t}\right)=\ln \left(k_{d}^{*}-k_{f}^{*}\right)$, a commonly employed dependent variable in empirical analysis of political risk and FDI. Because this measure is undefined for negative net inflows $\left(k_{d}^{*}<k_{f}^{*}\right)$, a useful monotonic transformation employed in this literature (e.g., Busse and Hefeker, 2007) follows Burbidge et al. (1988) by first transforming $k_{i t}^{\text {net }}$ using the monotonic function

$$
\phi(x)=\left(x+\sqrt{x^{2}+1}\right) .
$$

The natural $\log$ of $\phi(x)$ approximates $\ln (x)$ at high values of $x$, but becomes linear around zero, accommodating negative observations. Using expressions (D.1) and (D.2), it is straightforward to verify that

$$
\frac{\partial \ln \left(\phi\left(k^{n e t}\right)\right)}{\partial z_{d}^{*}}=\frac{\phi^{\prime}\left(k^{n e t}\right)}{\phi\left(k^{n e t}\right)} \cdot \beta_{d} k_{d}^{*}=\beta_{d}\left(\frac{k_{d}^{*}}{\sqrt{\left(k^{n e t}\right)^{2}+1}}\right) .
$$

Although the relationship between $z_{d}^{*}$ and $k^{n e t}$ is strictly positive for all values of $k^{n e t}$, it becomes more nonlinear as the level of inflows approaches outflows. Holding outflows constant (which are determined by the average level of taxes and institutional quality in the foreign countries, $\tau_{f}$ and $z_{f}^{*}$ ), as inflows increase, the marginal effect of $z_{d}^{*}$ on $k^{n e t}$ approaches $\beta_{d}$. Conversely, as inflows decrease toward the level of outflows, $k^{n e t}$ becomes small relative to $k_{d}^{*}$ and the marginal effect of $z_{d}^{*}$ on $k^{\text {net }}$ increases above $\beta_{d}$.

To illustrate how a log-linear empirical model may produce biased estimates of the true average effect of $z_{d}^{*}$ on net inflows, consider the average marginal effect across coun- 
tries, $\hat{\beta}_{d}$. In countries characterized by positive net inflows but relatively low levels of inflows (given outflows), the marginal effect will exceed the average effect, while the opposite is true of countries with relatively high levels of inflows. Inspection of (D.1) reveals that countries with relatively low levels of inflows are also those with relatively low values of $z_{d}^{*}$. Therefore, the true marginal effect will tend to exceed the average effect $\hat{\beta}_{d}$ for countries with below-average values of $z_{d}^{*}$ and will tend to be below the average effect for countries with above-average values of $z_{d}^{*}$. This suggests that the estimated average effect of risk on net flows will be biased towards zero in samples of countries with positive net flows (which describes the vast majority developing countries). The same conclusions are reached when estimating the marginal effect of $z_{d}^{*}$ or $z_{f}^{*}$ on $k^{\text {net }}$ in terms of levels rather than logs, and for any monotonic transformation of the dependent variable. 


\section{Online Appendix 1: Macroeconomic Variables and Data Sources}

\begin{tabular}{|c|c|c|}
\hline Variable & Definition & Source \\
\hline Net FDI per capita & $\begin{array}{l}\text { FDI inflows minus FDI outflows } \\
\text { per capita (US dollars at } \\
\text { current prices and exchange rates) }\end{array}$ & UNCTAD (2016) \\
\hline Gross FDI inflows & $\begin{array}{l}\text { FDI inflows net of profit repatriation } \\
\text { and other disinvestments } \\
\text { (current US dollars) }\end{array}$ & UNCTAD (2016) \\
\hline $\begin{array}{l}\text { Gross FDI inflows } \\
\text { per capita }\end{array}$ & $\begin{array}{l}\text { Gross FDI inflows divided by } \\
\text { total population } \\
\text { (current US dollars) }\end{array}$ & UNCTAD (2016) \\
\hline $\begin{array}{l}\text { Government } \\
\text { Consumption }\end{array}$ & $\begin{array}{l}\text { Government consumption } \\
\text { (Share of GNI) }\end{array}$ & WDI, World Bank (2016) \\
\hline GNI & $\begin{array}{l}\text { Gross National Income, } \\
\text { PPP (current international dollars) }\end{array}$ & WDI, World Bank (2016) \\
\hline GNI per capita & $\begin{array}{l}\text { Gross National Income per capita, } \\
\text { PPP (current international dollars) }\end{array}$ & WDI, World Bank (2016) \\
\hline $\begin{array}{l}\text { GNI per capita } \\
\text { growth }\end{array}$ & $\begin{array}{l}\text { Gross National Income per capita } \\
\text { growth (annual \%) }\end{array}$ & WDI, World Bank (2016) \\
\hline Inflation & GDP deflator (annual \%) & WDI, World Bank (2016) \\
\hline Trade & $\begin{array}{l}\text { Sum of exports and imports } \\
\text { ( } \% \text { of GDP) }\end{array}$ & WDI, World Bank (2016) \\
\hline
\end{tabular}


Online Appendix 2: Summary Statistics for 12 ICRG Political Risk Indexes Using Estimation Sample from Model D

\begin{tabular}{lccccc}
\hline VARIABLES & Obs. & Mean & Std. Dev. & Min & Max \\
& & & & & \\
\hline Exprop. Risk Absent & 653 & 5.69 & 1.70 & 0.84 & 9.69 \\
Law and Order & 653 & 5.13 & 1.93 & 0.35 & 10 \\
Bureaucratic Quality & 653 & 2.93 & 1.50 & 0 & 6.67 \\
Corruption Absent & 653 & 4.21 & 1.57 & 0 & 9.72 \\
Democratic Accountability & 653 & 5.79 & 2.24 & 0 & 10 \\
Military Absent in Politics & 653 & 5.38 & 2.75 & 0 & 10 \\
Ethnic Tensions Absent & 653 & 6.17 & 2.27 & 0 & 10 \\
Religious Tensions Absent & 640 & 7.67 & 2.10 & 0 & 10 \\
Socioecon. Stress Absent & 653 & 4.06 & 1.41 & 0 & 8.09 \\
Internal Conflict Absent & 653 & 6.86 & 1.87 & 0.02 & 10 \\
External Conflict Absent & 653 & 7.88 & 1.60 & 0 & 10 \\
Government Stability & 653 & 6.09 & 1.60 & 1.06 & 9.44 \\
\hline
\end{tabular}


Online Appendix 3: Summary Statistics of Five Semi-Aggregated Composite Political Risk Measures Based on the Four Taxonomies Defined in Table 1, Estimation Sample for Model D

\begin{tabular}{|c|c|c|c|c|c|}
\hline VARIABLES & Obs & Mean & Std. Dev. & Min & $\operatorname{Max}$ \\
\hline \multicolumn{6}{|l|}{ Taxonomy 1} \\
\hline Exprop. Risk Absent Comp. & 653 & 5.41 & 1.50 & 1.32 & 9.01 \\
\hline Government Efficiency Comp. & 653 & 3.57 & 1.27 & 0.00 & 8.19 \\
\hline Government Stability Comp. & 653 & 5.08 & 1.08 & 1.20 & 8.55 \\
\hline Political Accountability Comp. & 637 & 6.26 & 1.60 & 1.78 & 9.58 \\
\hline Conflicts Absent Comp. & 653 & 7.37 & 1.55 & 0.01 & 10 \\
\hline \multicolumn{6}{|l|}{ Taxonomy 2} \\
\hline Exprop. Risk Absent Comp. & 653 & 5.69 & 1.70 & 0.84 & 9.69 \\
\hline Government Efficiency Comp. & 653 & 4.09 & 1.28 & 0.56 & 8.22 \\
\hline Government Stability Comp. & 653 & 5.08 & 1.08 & 1.20 & 8.55 \\
\hline Political Accountability Comp. & 637 & 6.26 & 1.60 & 1.78 & 9.58 \\
\hline Conflicts Absent Comp. & 653 & 7.37 & 1.55 & 0 & 10 \\
\hline \multicolumn{6}{|l|}{ Taxonomy 3} \\
\hline Exprop. Risk Absent Comp. & 653 & 5.41 & 1.50 & 1.32 & 9.01 \\
\hline Government Efficiency Comp. & 653 & 3.57 & 1.27 & 0 & 8.19 \\
\hline Government Stability Comp. & 637 & 6.59 & 1.27 & 2.19 & 9.09 \\
\hline Political Accountability Comp. & 653 & 5.58 & 2.16 & 0.16 & 10 \\
\hline Conflicts Absent Comp. & 653 & 7.88 & 1.60 & 0 & 10 \\
\hline \multicolumn{6}{|l|}{ Taxonomy 4} \\
\hline Exprop. Risk Absent Comp. & 653 & 5.64 & 1.37 & 1.41 & 9.03 \\
\hline Government Efficiency Comp. & 653 & 3.57 & 1.27 & 0 & 8.19 \\
\hline Government Stability Comp. & 653 & 4.06 & 1.41 & 0 & 8.09 \\
\hline Political Accountability Comp. & 637 & 6.26 & 1.60 & 1.78 & 9.58 \\
\hline Conflicts Absent Comp. & 653 & 7.37 & 1.55 & 0.01 & 10 \\
\hline
\end{tabular}


Online Appendix 4: Summary Statistics for 12 ICRG Political Risk Indexes and Control Variables Using All Available Observations

\begin{tabular}{lccccc}
\hline VARIABLES & Obs. & Mean & Std. Dev. & Min & Max \\
& & & & & \\
\hline Exprop. Risk Absent & 661 & 5.67 & 1.70 & 0.84 & 9.69 \\
Law and Order & 661 & 5.16 & 1.93 & 0.35 & 10.0 \\
Bureaucratic Quality & 661 & 2.92 & 1.49 & 0 & 6.67 \\
Corruption Absent & 661 & 4.21 & 1.57 & 0 & 9.72 \\
Democratic Accountability & 661 & 5.74 & 2.26 & 0 & 10 \\
Military Absent in Politics & 661 & 5.35 & 2.74 & 0 & 10 \\
Ethnic Tensions Absent & 661 & 6.18 & 2.27 & 0 & 10 \\
Religious Tensions Absent & 648 & 7.69 & 2.10 & 0 & 10 \\
Socioecon. Stress Absent & 661 & 4.06 & 1.41 & 0 & 8.09 \\
Internal Conflict Absent & 661 & 6.87 & 1.87 & 0.02 & 10 \\
External Conflict Absent & 661 & 7.86 & 1.61 & 0 & 10 \\
Government Stability & 661 & 6.10 & 1.60 & 1.06 & 9.44 \\
& & & & & \\
Gov. Expenditure (\% of GDP) & 632 & 14.3 & 5.51 & 2.80 & 50.0 \\
Log Population & 664 & 16.5 & 1.48 & 13.5 & 21.0 \\
Log GNI Growth & 550 & 1.03 & 1.45 & -3.30 & 3.58 \\
Log GNI per Capita & 642 & 7.28 & 1.22 & 3.97 & 10.2 \\
Log GNI & 561 & 8.39 & 1.06 & 5.97 & 10.9 \\
Log Trade & 640 & 4.13 & 0.49 & 2.54 & 5.49 \\
Log Inflation & 647 & 2.76 & 1.58 & -3.00 & 9.70 \\
\hline
\end{tabular}


Online Appendix 5: Summary Statistics of Five Semi-Aggregated Composite Political Risk Measures Based on the Four Respective Taxonomies Defined in Table 1 Using All Available Observations

\begin{tabular}{|c|c|c|c|c|c|}
\hline VARIABLES & Obs & Mean & Std. Dev. & Min & Max \\
\hline \multicolumn{6}{|l|}{ Taxonomy 1} \\
\hline Exprop. Risk Absent Comp. & 661 & 5.42 & 1.49 & 1.32 & 9.01 \\
\hline Government Efficiency Comp. & 661 & 3.56 & 1.27 & 0 & 8.19 \\
\hline Government Stability Comp. & 661 & 5.09 & 1.08 & 1.20 & 8.55 \\
\hline Political Accountability Comp. & 645 & 6.25 & 1.60 & 1.78 & 9.58 \\
\hline Conflicts Absent Comp. & 661 & 7.37 & 1.56 & 0.01 & 10 \\
\hline \multicolumn{6}{|l|}{ Taxonomy 2} \\
\hline Exprop. Risk Absent Comp. & 661 & 5.67 & 1.70 & 0.84 & 9.69 \\
\hline Government Efficiency Comp. & 661 & 4.10 & 1.28 & 0.56 & 8.22 \\
\hline Government Stability Comp. & 661 & 5.09 & 1.08 & 1.20 & 8.55 \\
\hline Political Accountability Comp. & 645 & 6.25 & 1.60 & 1.78 & 9.58 \\
\hline Conflicts Absent Comp. & 661 & 7.37 & 1.56 & 0.01 & 10 \\
\hline \multicolumn{6}{|l|}{ Taxonomy 3} \\
\hline Exprop. Risk Absent Comp. & 661 & 5.42 & 1.49 & 1.32 & 9.01 \\
\hline Government Efficiency Comp. & 661 & 3.56 & 1.27 & 0 & 8.19 \\
\hline Government Stability Comp. & 645 & 6.60 & 1.27 & 2.19 & 9.51 \\
\hline Political Accountability Comp. & 661 & 5.55 & 2.17 & 0.16 & 10 \\
\hline Conflicts Absent Comp. & 661 & 7.86 & 1.61 & 0 & 10 \\
\hline \multicolumn{6}{|l|}{ Taxonomy 4} \\
\hline Exprop. Risk Absent Comp. & 661 & 5.65 & 1.37 & 1.41 & 9.03 \\
\hline Government Efficiency Comp. & 661 & 3.56 & 1.27 & 0 & 8.19 \\
\hline Government Stability Comp. & 661 & 4.06 & 1.41 & 0 & 8.09 \\
\hline Political Accountability Comp. & 645 & 6.25 & 1.60 & 1.78 & 9.58 \\
\hline Conflicts Absent Comp. & 661 & 7.37 & 1.56 & 0.01 & 10 \\
\hline
\end{tabular}


Online Appendix 6: Fixed Effects and GMM Estimates of Models A, B, C, D Including Each of 12 ICRG Political Risk Measures One at a Time (c.f., Busse and Hefeker, 2007)

\begin{tabular}{|c|c|c|c|c|c|c|c|c|c|c|c|c|c|c|c|c|}
\hline \multirow[b]{3}{*}{ VARIABLES } & \multicolumn{8}{|c|}{ FE Models } & \multicolumn{8}{|c|}{ GMM Models } \\
\hline & \multicolumn{2}{|c|}{$\begin{array}{l}\text { A (Net FDI): BH } \\
\text { (2007) Model } \\
\text { adding Gov } \\
\text { Expenditure as } \\
\text { control with } 12 \\
\text { more years of } \\
\text { data (1984-2015) }\end{array}$} & \multicolumn{2}{|c|}{$\begin{array}{l}B(\text { Gross FDI }): \\
\text { Model A with log } \\
\text { Gross FDI per } \\
\text { capita instead of } \\
\text { log Net FDI per } \\
\text { capita as the } \\
\text { dependent } \\
\text { variable }\end{array}$} & \multicolumn{2}{|c|}{$\begin{array}{l}C \text { (Gross FDI): } \\
\text { Model B with a } \\
\text { single income } \\
\text { control, log GNI } \\
\text { per capita, } \\
\text { instead of } \\
\text { double-inclusion } \\
\text { of growth }\end{array}$} & \multicolumn{2}{|c|}{$\begin{array}{l}D(\text { Gross FDI }) \text { : } \\
\text { Model C with } \\
\text { more flexible } \\
\text { specification for } \\
\text { impacts of } \\
\text { income and } \\
\text { market size }\end{array}$} & \multicolumn{2}{|c|}{$\begin{array}{l}\text { A (Net FDI): BH } \\
(2007) \text { Model } \\
\text { adding Gov } \\
\text { Expenditure as } \\
\text { control with } 12 \\
\text { more years of } \\
\text { data (1984-2015) }\end{array}$} & \multicolumn{2}{|c|}{$\begin{array}{l}\text { B }(\text { Gross FDI }): \\
\text { Model A with log } \\
\text { Gross FDI per } \\
\text { capita instead of } \\
\text { log Net FDI per } \\
\text { capita as the } \\
\text { dependent } \\
\text { variable }\end{array}$} & \multicolumn{2}{|c|}{$\begin{array}{l}C(\text { Gross FDI): } \\
\text { Model B with a } \\
\text { single income } \\
\text { control, log GNI } \\
\text { per capita, } \\
\text { instead of } \\
\text { double-inclusion } \\
\text { of growth }\end{array}$} & \multicolumn{2}{|c|}{$\begin{array}{l}D(\text { Gross FDI }) \text { : } \\
\text { Model C with } \\
\text { more flexible } \\
\text { specification for } \\
\text { impacts of } \\
\text { income and } \\
\text { market size }\end{array}$} \\
\hline & coef & $\mathrm{t}$ stat & coef & t stat & coef & tstat & coef & tstat & coef & tstat & coef & tstat & coef & tstat & coef & tstat \\
\hline Exprop. Risk Absent & 0.03 & 0.28 & $0.26^{* * * *}$ & 2.64 & $0.34 * * *$ & 3.48 & $0.41^{* * * *}$ & 4.11 & 0.05 & 0.30 & $0.26^{* *}$ & 2.08 & $0.34^{* * * *}$ & 2.76 & $0.36^{* * * *}$ & 2.85 \\
\hline Law and Order & -0.05 & -0.40 & 0.07 & 1.26 & $0.13^{* *}$ & 2.22 & $0.18 * *$ & 2.44 & -0.27 & -1.28 & 0.11 & 1.25 & 0.15 & 1.61 & $0.16^{*}$ & 1.77 \\
\hline Bureaucratic Quality & -0.15 & -0.94 & 0.02 & 0.16 & 0.08 & 0.74 & 0.01 & 0.12 & 0.02 & 0.09 & 0.01 & 0.05 & -0.04 & -0.28 & -0.06 & -0.33 \\
\hline Corruption Absent & 0.06 & 0.43 & 0.10 & 1.05 & 0.14 & 1.58 & $0.20 * *$ & 2.08 & 0.00 & -0.01 & $0.23 * *$ & 2.16 & $0.18^{*}$ & 1.92 & $0.19 * *$ & 1.98 \\
\hline Democratic Account. & -0.03 & -0.36 & 0.05 & 0.54 & 0.10 & 1.22 & 0.09 & 1.12 & -0.08 & -0.74 & -0.07 & -0.92 & -0.010 & -0.17 & -0.02 & -0.26 \\
\hline Military Absent in Politics & 0.00 & -0.06 & 0.08 & 0.93 & 0.10 & 1.38 & $0.13 * *$ & 2.11 & 0.16 & 1.61 & $0.12 *$ & 1.83 & $0.18 * *$ & 2.43 & $0.18^{* *}$ & 2.43 \\
\hline Ethnic Tensions Absent & -0.03 & -0.26 & 0.04 & 0.53 & 0.09 & 1.28 & $0.12 *$ & 1.81 & 0.12 & 0.98 & 0.030 & 0.49 & 0.04 & 0.67 & 0.05 & 0.77 \\
\hline Religious Tensions Absent & 0.22 & 1.19 & -0.03 & -0.49 & 0.03 & 0.60 & 0.06 & 1.04 & $0.29 *$ & 1.81 & 0.07 & 0.80 & 0.00 & 0.04 & 0.02 & 0.17 \\
\hline Socioecon. Stress Absent & -0.19 & -1.03 & 0.17 & 1.44 & $0.24 *$ & 1.90 & $0.29 * *$ & 2.40 & 0.09 & 0.47 & 0.21 & 1.23 & $0.26^{*}$ & 1.78 & $0.26^{*}$ & 1.91 \\
\hline Internal Conflict Absent & 0.07 & 0.91 & $0.08^{*}$ & 1.70 & 0.04 & 0.59 & 0.10 & 1.52 & $0.21 *$ & 1.70 & $0.22 * *$ & 2.53 & $0.20 * *$ & 2.48 & $0.21 * *$ & 2.56 \\
\hline External Conflict Absent & 0.11 & 1.18 & 0.06 & 0.93 & 0.03 & 0.40 & 0.05 & 0.66 & 0.04 & 0.13 & 0.06 & 0.60 & -0.01 & -0.10 & -0.01 & -0.09 \\
\hline Government Stability & 0.15 & 0.98 & $0.20 * *$ & 2.34 & $0.24 * * *$ & 2.82 & $0.26^{* * * *}$ & 2.68 & 0.30 & 1.51 & $0.19^{*}$ & 1.93 & $0.21 * *$ & 2.02 & $0.22 * *$ & 2.05 \\
\hline
\end{tabular}

${ }^{1}$ The t-statistics are computed using the "cluster" command for standard errors in FE estimation and "robust” for standard errors in GMM estimation. The asterisks “***," “**," and “*” denote statistical significance at the $1 \%, 5 \%$ and $10 \%$ levels, respectively. The number of estimates in this table correspond to 12 (ICRG indexes) $\times 4$ (Models A-D) $\mathrm{x} \times 2$ (FE and GMM) $=96$ empirical models from which the coefficient and t-statistic for the political risk variable in each model is tabled above. All models include country and time effects. 
Online Appendix 7: FE and GMM Coefficient Estimates Using Taxonomy 1 (Defined in Table 1) with Semi-Aggregated Composite Political Risk Measures Included One at a Time

\begin{tabular}{|c|c|c|c|c|c|c|c|c|c|c|c|c|c|c|c|c|c|c|c|c|}
\hline \multirow[b]{3}{*}{ VARIABLES } & \multicolumn{10}{|c|}{ FE Models } & \multicolumn{10}{|c|}{ GMM Models } \\
\hline & \multicolumn{2}{|c|}{$\begin{array}{l}\text { Exprop. } \\
\text { Risk Absent } \\
\text { Comp. }\end{array}$} & \multicolumn{2}{|c|}{$\begin{array}{l}\text { Gov. Eff. } \\
\text { Comp. }\end{array}$} & \multicolumn{2}{|c|}{$\begin{array}{l}\text { Gov. Stab. } \\
\text { Comp. }\end{array}$} & \multicolumn{2}{|c|}{$\begin{array}{c}\text { Political } \\
\text { Acc. Comp. }\end{array}$} & \multicolumn{2}{|c|}{$\begin{array}{c}\text { Conflicts } \\
\text { Absent } \\
\text { Comp. }\end{array}$} & \multicolumn{2}{|c|}{$\begin{array}{l}\text { Exprop. } \\
\text { Risk Absent } \\
\text { Comp. }\end{array}$} & \multicolumn{2}{|c|}{$\begin{array}{l}\text { Gov. Eff. } \\
\text { Comp. }\end{array}$} & \multicolumn{2}{|c|}{$\begin{array}{l}\text { Gov. Stab. } \\
\text { Comp. }\end{array}$} & \multicolumn{2}{|c|}{$\begin{array}{c}\text { Political } \\
\text { Acc. Comp. }\end{array}$} & \multicolumn{2}{|c|}{$\begin{array}{c}\text { Conflicts } \\
\text { Absent } \\
\text { Comp. }\end{array}$} \\
\hline & coef & tstat & coef & tstat & coef & tstat & coef & tstat & coef & tstat & coef & tstat & coef & tstat & coef & tstat & coef & tstat & coef & tstat \\
\hline $\begin{array}{l}\text { Institutional } \\
\text { Quality }\end{array}$ & $0.50 * * *$ & 4.03 & $0.19 *$ & 1.79 & $0.48^{* * * *}$ & 3.32 & $0.24 * *$ & 2.22 & 0.11 & 1.25 & $0.43 * * *$ & 2.88 & 0.18 & 1.10 & $0.43^{* *}$ & 2.565 & 0.13 & 1.52 & 0.17 & 1.50 \\
\hline Gov Expenditure & 0.04 & 0.53 & 0.02 & 0.23 & 0.03 & 0.45 & 0.02 & 0.28 & 0.03 & 0.37 & -0.04 & -1.05 & -0.05 & -1.36 & -0.04 & -1.03 & -0.05 & -1.21 & -0.05 & -1.19 \\
\hline Log Pop & -0.91 & -0.67 & -0.17 & -0.13 & -0.03 & -0.03 & -0.24 & -0.18 & -0.34 & -0.27 & 0.06 & 0.12 & -0.43 & -0.73 & -0.11 & -0.17 & -0.35 & -0.61 & -0.44 & -0.71 \\
\hline Log GNI & -0.57 & -0.90 & -0.14 & -0.23 & -0.45 & -0.69 & -0.04 & -0.07 & 0.02 & 0.04 & 0.04 & 0.11 & 0.54 & 1.36 & 0.19 & 0.54 & 0.55 & 1.54 & $0.61 *$ & 1.73 \\
\hline Log Trade & 0.23 & 0.68 & 0.17 & 0.44 & 0.18 & 0.49 & 0.27 & 0.71 & 0.17 & 0.45 & $0.98^{*}$ & 1.96 & $0.99 * *$ & 1.98 & $1.03 * *$ & 1.99 & $1.02 * *$ & 2.02 & $0.98^{*}$ & 1.90 \\
\hline Log Inflation & 0.03 & 0.28 & -0.06 & -0.52 & -0.01 & -0.06 & -0.01 & -0.06 & -0.04 & -0.42 & 0.07 & 0.75 & 0.03 & 0.35 & 0.06 & 0.64 & 0.05 & 0.52 & 0.04 & 0.43 \\
\hline FDI (lagged) & & & & & & & & & & & $0.54 * * *$ & 3.84 & $0.57^{* * *}$ & 4.10 & $0.56^{* * *}$ & 4.168 & $0.58^{* * * *}$ & 4.10 & $0.57 * * *$ & 4.16 \\
\hline Constant & 17.96 & 0.74 & 7.79 & 0.32 & 6.21 & 0.26 & 3.79 & 0.17 & 5.97 & 0.27 & 1.37 & 0.16 & 0.72 & 0.08 & 0.96 & 0.114 & -0.63 & -0.07 & -1.57 & -0.18 \\
\hline \#Observations & 543 & & 543 & & 543 & & 531 & & 543 & & 538 & & 538 & & 538 & & 526 & & 538 & \\
\hline R-squared & 0.475 & & 0.44 & & 0.46 & & 0.429 & & 0.437 & & & & & & & & & & & \\
\hline \#Countries & 82 & & 82 & & 82 & & 82 & & 82 & & 82 & & 82 & & 82 & & 82 & & 82 & \\
\hline
\end{tabular}


Online Appendix 8: Expected Percentage Change in FDI Based on FE and GMM Coefficients Estimated One at a Time from Appendix 1A (Semi-Aggregated Composite Political Risk Measures, Taxonomy 1)

\begin{tabular}{|c|c|c|c|c|c|c|c|c|c|c|c|c|c|c|}
\hline \multirow[b]{2}{*}{ VARIABLES } & \multicolumn{6}{|c|}{$\begin{array}{l}\text { (a) Expected Percentage Changes in FDI and Importance Rankings } \\
\text { from a One-Standard-Deviation Improvement in Institutional Quality }\end{array}$} & \multicolumn{8}{|c|}{$\begin{array}{l}\text { (b) Expected Percentage Changes in FDI and Importance Rankings } \\
\text { from a Worst-to-Best Improvement in Institutional Quality }\end{array}$} \\
\hline & $\begin{array}{c}\text { Fixed } \\
\text { Effects } \\
\text { Coef. }\end{array}$ & $\begin{array}{c}\text { Model } \\
\text { D Fixed } \\
\text { Effects }\end{array}$ & $\begin{array}{l}\text { Rank in } \\
\text { Fixed } \\
\text { Effects }\end{array}$ & $\begin{array}{l}\text { GMM } \\
\text { Coef. }\end{array}$ & $\begin{array}{c}\text { Model } \\
\text { D } \\
\text { GMM }\end{array}$ & $\begin{array}{l}\text { Rank } \\
\text { in } \\
\text { GMM }\end{array}$ & $\begin{array}{l}\text { Mean } \\
\text { Rank }\end{array}$ & $\begin{array}{l}\text { Fixed } \\
\text { Effects } \\
\text { Coef. }\end{array}$ & $\begin{array}{c}\text { Model } \\
\text { D Fixed } \\
\text { Effects }\end{array}$ & $\begin{array}{l}\text { Rank in } \\
\text { Fixed } \\
\text { Effects }\end{array}$ & $\begin{array}{l}\text { GMM } \\
\text { Coef. }\end{array}$ & $\begin{array}{c}\text { Model } \\
\text { D GMM }\end{array}$ & $\begin{array}{c}\text { Rank } \\
\text { in } \\
\text { GMM }\end{array}$ & $\begin{array}{l}\text { Mean } \\
\text { Rank }\end{array}$ \\
\hline Exprop. Risk Absent Comp. & $0.50 * * *$ & $75 \%$ & 1 & $0.43 * * *$ & $64 \%$ & 1 & 1 & $0.48 * * *$ & $385 \%$ & 1 & $0.37 * * *$ & $331 \%$ & 1 & 1 \\
\hline Government Efficiency Comp. & $0.19 *$ & $24 \%$ & 4 & 0.18 & $23 \%$ & 4 & 4 & $0.16^{*}$ & $156 \%$ & 4 & 0.14 & $148 \%$ & 4 & 4 \\
\hline Government Stability Comp. & $0.48 * * *$ & $52 \%$ & 2 & $0.43^{* *}$ & $47 \%$ & 2 & 2 & $0.44 * * *$ & $353 \%$ & 2 & $0.31 * *$ & $316 \%$ & 2 & 2 \\
\hline Political Accountability Comp. & $0.24 * *$ & $38 \%$ & 3 & 0.13 & $21 \%$ & 5 & 4 & $0.29 * * *$ & $187 \%$ & 3 & $0.21 * *$ & $101 \%$ & 5 & 4 \\
\hline Conflicts Absent Comp. & 0.11 & $17 \%$ & 5 & 0.17 & $26 \%$ & 3 & 4 & $0.17 * *$ & $110 \%$ & 5 & 0.14 & $170 \%$ & 3 & 4 \\
\hline
\end{tabular}

${ }^{1}$ Marginal effects are based on the Model D coefficient estimates and estimation sample when computing empirical ranges and standard deviations. However, relative rankings are largely insensitive to

choice of estimation samples used to model observable ranges. The asterisks “***," “**," and "**” denote statistical significance at the $1 \%, 5 \%$ and $10 \%$ levels, respectively. 


\section{Online Appendix 9A: Factor Loadings of 12 ICRG Political Risk Measures}

\begin{tabular}{lccc}
\hline & & & \\
VARIABLES & Factor 1 & Factor 2 & Factor 3 \\
\hline Expropriation Risk Absent & 0.66 & -0.37 & -0.39 \\
Law and Order & 0.71 & -0.01 & 0.32 \\
Bureaucratic Quality & 0.67 & 0.33 & -0.29 \\
Corruption Absent & 0.49 & 0.57 & 0.24 \\
Democratic Accountability & 0.60 & 0.13 & -0.41 \\
Military Not in Politics & 0.75 & 0.23 & -0.19 \\
Ethnic Tensions Absent & 0.58 & -0.11 & 0.40 \\
Religious Tensions Absent & 0.33 & 0.23 & 0.51 \\
Socioecon Stress Absent & 0.55 & 0.38 & -0.18 \\
Internal Conflict Absent & 0.80 & -0.27 & 0.19 \\
External Conflict Absent & 0.60 & -0.33 & 0.02 \\
Government Stability & 0.46 & -0.69 & 0.05 \\
Eigenvalues & 4.53 & 1.51 & 1.09 \\
\hline
\end{tabular}

\section{Online Appendix 9B: Fixed-Effects and GMM Estimates Using Principal Factors with Eigenvalues Greater than 1, Estimated Using Model D Specification}

\begin{tabular}{|c|c|c|c|c|}
\hline & \multicolumn{2}{|c|}{ Fixed Effects } & \multicolumn{2}{|c|}{$G M M$} \\
\hline & coef & $\mathrm{t}$ stat & coef & $\mathrm{t}$ stat \\
\hline Factor 1 & $0.63 * * *$ & 3.49 & $0.58 * * *$ & 2.66 \\
\hline Factor 2 & -0.12 & -0.95 & -0.14 & -0.71 \\
\hline Factor 3 & -0.1 & -0.46 & -0.01 & -0.07 \\
\hline Gov Expenditure & 0.03 & 0.45 & -0.02 & -0.61 \\
\hline Log Pop & -0.67 & -0.54 & 0.03 & 0.08 \\
\hline Log GNI & -0.45 & -0.82 & -0.41 & -0.62 \\
\hline Log Trade & 0.24 & 0.68 & 0.53 & 1.29 \\
\hline Log Inflation & 0.03 & 0.26 & 0.05 & 0.85 \\
\hline FDI (lagged) & & & $0.55^{* * *}$ & 3.98 \\
\hline Obs. & 531 & & 526 & \\
\hline R-squared & 0.445 & & & \\
\hline \# of Countries & 82 & & 82 & \\
\hline Sargan (p-value) & & & 0.10 & \\
\hline
\end{tabular}


Online Appendix 10: Simulated Expected Percentage Change in FDI Inflows from Ceteris Paribus (a) One-StandardDeviation and (b) Worst-to-Best Improvements in a Single Measure of Institutional Quality (Estimated Simultaneously with Five Semi-Aggregated Composite Political Risk Measures Based on the Four Taxonomies in Table 1)

$\begin{array}{ll}\text { (a) Expected Percentage Changes in FDI and Importance Rankings } & \text { (b) Expected Percentage Changes in FDI and Importance Rankings }\end{array}$ from a One-Standard-Deviation Improvement in Institutional Quality from a Worst-to-Best Improvement in Institutional Quality

\begin{tabular}{|c|c|c|c|c|c|c|c|c|c|c|c|c|c|c|}
\hline VARIABLES & $\begin{array}{l}\text { Fixed } \\
\text { Effects } \\
\text { Coef. }\end{array}$ & $\begin{array}{l}\text { Model } \\
\text { D Fixed } \\
\text { Effects }\end{array}$ & $\begin{array}{l}\text { Rank in } \\
\text { Fixed } \\
\text { Effects }\end{array}$ & $\begin{array}{l}\text { GMM } \\
\text { Coef. }\end{array}$ & $\begin{array}{l}\text { Model } \\
\text { D } \\
\text { GMM }\end{array}$ & $\begin{array}{c}\text { Rank } \\
\text { in } \\
\text { GMM }\end{array}$ & $\begin{array}{l}\text { Mean } \\
\text { Rank }\end{array}$ & $\begin{array}{l}\text { Fixed } \\
\text { Effects } \\
\text { Coef. }\end{array}$ & $\begin{array}{l}\text { Model } \\
\text { D Fixed } \\
\text { Effects }\end{array}$ & $\begin{array}{l}\text { Rank in } \\
\text { Fixed } \\
\text { Effects }\end{array}$ & $\begin{array}{l}\text { GMM } \\
\text { Coef. }\end{array}$ & $\begin{array}{c}\text { Model } \\
\text { D GMM }\end{array}$ & $\begin{array}{l}\text { Rank } \\
\text { in } \\
\text { GMM }\end{array}$ & $\begin{array}{l}\text { Mean } \\
\text { Rank }\end{array}$ \\
\hline \multicolumn{15}{|l|}{ Taxonomy 1} \\
\hline Exprop. Risk Absent Comp. & $0.37 * * *$ & $74 \%$ & 1 & $0.33^{* *}$ & $64 \%$ & 1 & 1 & $0.37 * * *$ & $1621 \%$ & 1 & $0.33^{* *}$ & $1165 \%$ & 1 & 1 \\
\hline Government Efficiency Comp. & 0.05 & $7 \%$ & 4 & 0.05 & $7 \%$ & 3 & 3.5 & 0.05 & $51 \%$ & 4 & 0.05 & $51 \%$ & 3 & 3.5 \\
\hline Government Stability Comp. & $0.32 * *$ & $41 \%$ & 2 & $0.28^{*}$ & $35 \%$ & 2 & 2 & $0.32 * *$ & $953 \%$ & 2 & $0.28 *$ & $685 \%$ & 2 & 2 \\
\hline Political Accountability Comp. & 0.10 & $17 \%$ & 3 & -0.06 & $-9 \%$ & 5 & 4 & 0.10 & $118 \%$ & 3 & -0.06 & $-37 \%$ & 5 & 4 \\
\hline Conflicts Absent Comp. & -0.12 & $-17 \%$ & 5 & 0.00 & $0 \%$ & 4 & 4.5 & -0.12 & $-70 \%$ & 5 & 0.00 & $0 \%$ & 4 & 4.5 \\
\hline \multicolumn{15}{|l|}{ Taxonomy 2} \\
\hline Exprop. Risk Absent Comp. & $0.31 * * *$ & $69 \%$ & 1 & $0.27 * *$ & $58 \%$ & 1 & 1 & $0.31 * * *$ & $1452 \%$ & 1 & $0.27 * *$ & $989 \%$ & 1 & 1 \\
\hline Government Efficiency Comp. & 0.14 & $20 \%$ & 4 & 0.13 & $18 \%$ & 3 & 3.5 & 0.14 & $193 \%$ & 3 & 0.13 & $171 \%$ & 3 & 3 \\
\hline Government Stability Comp. & $0.28 * *$ & $35 \%$ & 2 & 0.26 & $33 \%$ & 2 & 2 & $0.28 * *$ & $685 \%$ & 2 & 0.26 & $577 \%$ & 2 & 2 \\
\hline Political Accountability Comp. & 0.09 & $15 \%$ & 3 & -0.04 & $-6 \%$ & 5 & 4 & 0.09 & $102 \%$ & 4 & -0.04 & $-27 \%$ & 5 & 4.5 \\
\hline Conflicts Absent Comp. & -0.08 & $-12 \%$ & 5 & 0.05 & $8 \%$ & 4 & 4.5 & -0.08 & $-55 \%$ & 5 & 0.05 & $65 \%$ & 4 & 4.5 \\
\hline \multicolumn{15}{|l|}{ Taxonomy 3} \\
\hline Exprop. Risk Absent Comp. & $0.41 * * *$ & $85 \%$ & 1 & $0.36^{* *} *$ & $71 \%$ & 1 & 1 & $0.41 * * *$ & $2241 \%$ & 1 & $0.36^{* *}$ & $1494 \%$ & 1 & 1 \\
\hline Government Efficiency Comp. & 0.02 & $3 \%$ & 4 & 0.03 & $4 \%$ & 3 & 3.5 & 0.02 & $18 \%$ & 4 & 0.03 & $28 \%$ & 3 & 3.5 \\
\hline Government Stability Comp. & 0.17 & $24 \%$ & 2 & 0.24 & $36 \%$ & 2 & 2 & 0.17 & $247 \%$ & 2 & 0.24 & $479 \%$ & 2 & 2 \\
\hline Political Accountability Comp. & 0.04 & $9 \%$ & 3 & 0.00 & $0 \%$ & 4 & 3.5 & 0.04 & $48 \%$ & 3 & 0.00 & $0 \%$ & 4 & 3.5 \\
\hline Conflicts Absent Comp. & -0.09 & $-13 \%$ & 5 & -0.14 & $-20 \%$ & 5 & 5 & -0.09 & $-59 \%$ & 5 & -0.14 & $-75 \%$ & 5 & 5 \\
\hline \multicolumn{15}{|l|}{ Taxonomy 4} \\
\hline Exprop. Risk Absent Comp. & $0.59 * * *$ & $125 \%$ & 1 & $0.49 * *$ & $96 \%$ & 1 & 1 & $0.59 * * *$ & $8872 \%$ & 1 & $0.49 * *$ & $4087 \%$ & 1 & 1 \\
\hline Government Efficiency Comp. & 0.04 & $5 \%$ & 4 & 0.05 & $7 \%$ & 3 & 3.5 & 0.04 & $39 \%$ & 4 & 0.05 & $51 \%$ & 3 & 3.5 \\
\hline Government Stability Comp. & 0.09 & $13 \%$ & 3 & 0.13 & $20 \%$ & 2 & 2.5 & 0.09 & $107 \%$ & 3 & 0.13 & $186 \%$ & 2 & 2.5 \\
\hline Political Accountability Comp. & 0.10 & $17 \%$ & 2 & -0.05 & $-8 \%$ & 5 & 3.5 & 0.10 & $118 \%$ & 2 & -0.05 & $-32 \%$ & 5 & 3.5 \\
\hline Conflicts Absent Comp. & -0.14 & $-20 \%$ & 5 & 0.00 & $0 \%$ & 4 & 4.5 & -0.14 & $-75 \%$ & 5 & 0.00 & $0 \%$ & 4 & 4.5 \\
\hline
\end{tabular}

${ }^{1}$ Marginal effects are based on the Model D coefficient estimates and estimation sample when computing empirical ranges and standard deviations. However, the finding that Exprop. Risk Absent tends to have the largest impact on FDI is largely insensitive to choice of estimation samples used to model observable ranges. The asterisks “***," “**," and “*” denote statistical significance at the $1 \%$, $5 \%$ and $10 \%$ levels, respectively. The four taxonomies apply different definitions for the five semi-aggregated composite political risk variables as summarized in Table 1. 
Online Appendix 12: Robustness Check Adding Controls for Infrastructure and Human Capital to the Model D Specification with 5 Composite Political Risk Measures (across 4 Taxonomies) Simultaneously Included

\begin{tabular}{|c|c|c|c|c|c|c|c|c|c|c|c|c|c|c|c|c|}
\hline \multirow[b]{3}{*}{ VARIABLES } & \multicolumn{4}{|c|}{ Taxonomy 1} & \multicolumn{4}{|c|}{ Taxonomy 2} & \multicolumn{4}{|c|}{ Taxonomy 3} & \multicolumn{4}{|c|}{ Taxonomy 4} \\
\hline & \multicolumn{2}{|c|}{ FE } & \multicolumn{2}{|c|}{ GMM } & \multicolumn{2}{|c|}{$\mathbf{F E}$} & \multicolumn{2}{|c|}{ GMM } & \multicolumn{2}{|c|}{$\mathbf{F E}$} & \multicolumn{2}{|c|}{ GMM } & \multicolumn{2}{|c|}{ FE } & \multicolumn{2}{|c|}{ GMM } \\
\hline & coef & tstat & coef & tstat & coef & tstat & coef & tstat & coef & tstat & coef & tstat & coef & tstat & coef & tstat \\
\hline Exprop. Risk Absent Comp. & $0.28 * *$ & 2.32 & $0.28 *$ & 1.89 & $0.27 * * *$ & 3.05 & $0.29 * *$ & 2.19 & $0.31 * *$ & 2.52 & $0.32 * *$ & 2.05 & $0.40 * * *$ & 3.33 & $0.39 * *$ & 2.20 \\
\hline Government Efficiency Comp. & 0.01 & 0.14 & 0.18 & 1.00 & 0.06 & 0.51 & 0.18 & 1.08 & 0.00 & 0.04 & 0.15 & 0.90 & 0.01 & 0.13 & 0.18 & 1.02 \\
\hline Government Stability Comp. & $0.23 *$ & 1.72 & 0.25 & 1.18 & $0.20 *$ & 1.67 & 0.20 & 0.95 & 0.12 & 0.95 & 0.17 & 0.83 & 0.11 & 0.91 & 0.13 & 0.95 \\
\hline Political Accountability Comp. & 0.13 & 1.04 & -0.12 & -0.94 & 0.12 & 1.03 & -0.06 & -0.46 & 0.09 & 1.06 & -0.08 & -0.89 & 0.14 & 1.10 & -0.12 & -0.92 \\
\hline Conflicts Absent Comp. & -0.04 & -0.38 & -0.02 & -0.22 & -0.01 & -0.12 & -0.01 & -0.07 & -0.06 & -0.72 & -0.1 & -1.04 & -0.05 & -0.40 & -0.02 & -0.19 \\
\hline Gov Expenditure & 0.02 & 0.31 & -0.02 & -0.45 & 0.03 & 0.43 & -0.01 & -0.35 & 0.02 & 0.27 & -0.02 & -0.59 & 0.02 & 0.32 & -0.02 & -0.47 \\
\hline Log Pop & -0.28 & -0.27 & 0.54 & 0.70 & 0.09 & 0.09 & 0.65 & 0.87 & -0.39 & -0.39 & 0.66 & 0.79 & -0.29 & -0.28 & 0.54 & 0.71 \\
\hline Log GNI & -0.21 & -0.40 & -0.14 & -0.23 & -0.25 & -0.48 & -0.20 & -0.34 & -0.02 & -0.05 & 0.07 & 0.13 & -0.19 & -0.37 & -0.15 & -0.22 \\
\hline Log Trade & 0.17 & 0.56 & 0.56 & 1.23 & 0.20 & 0.67 & 0.64 & 1.37 & 0.17 & 0.53 & 0.65 & 1.48 & 0.17 & 0.56 & 0.54 & 1.25 \\
\hline Log Inflation & 0.05 & 0.46 & 0.09 & 1.25 & 0.05 & 0.47 & 0.09 & 1.24 & 0.04 & 0.45 & 0.08 & 1.13 & 0.04 & 0.46 & 0.09 & 1.26 \\
\hline Log Telephone line per 100 & -0.02 & -0.09 & -0.07 & -0.29 & 0.02 & 0.13 & -0.06 & -0.26 & -0.03 & -0.17 & -0.12 & -0.48 & -0.02 & -0.09 & -0.06 & -0.29 \\
\hline Log Schooling & -0.20 & -0.52 & $1.01 *$ & 1.87 & -0.20 & -0.51 & $1.03 *$ & 1.95 & -0.22 & -0.55 & $1.03^{*}$ & 1.74 & -0.21 & -0.56 & $1.03^{* *}$ & 2.04 \\
\hline FDI (Lagged) & & & $0.53 * * *$ & 3.62 & & & $0.52 * * *$ & 3.68 & & & $0.53 * * *$ & 3.51 & & & $0.53 * * *$ & 3.80 \\
\hline Constant & 5.56 & 0.31 & -14.0 & -1.05 & -0.56 & -0.03 & -16.34 & -1.24 & 6.83 & 0.38 & -18.03 & -1.16 & 5.64 & 0.31 & -13.9 & -1.05 \\
\hline \#Observations & 456 & & 451 & & 456 & & 451 & & 456 & & 451 & & 456 & & 451 & \\
\hline R-squared & 0.463 & & & & 0.47 & & & & 0.46 & & & & 0.463 & & & \\
\hline \#Countries & 80 & & 80 & & 80 & & 80 & & 80 & & 80 & & 80 & & 80 & \\
\hline
\end{tabular}




\section{Online Appendix 13: Random Effects Estimates of Models A, B, C, D of 12 ICRG Political Risk Measures}

\begin{tabular}{|c|c|c|c|c|c|c|c|c|}
\hline \multirow[b]{2}{*}{ VARIABLES } & \multicolumn{2}{|c|}{ Model A } & \multicolumn{2}{|c|}{ Model B } & \multicolumn{2}{|c|}{ Model C } & \multicolumn{2}{|c|}{ Model D } \\
\hline & coef & tstat & coef & tstat & coef & tstat & coef & tstat \\
\hline Exprop. Risk Absent & 0.08 & 0.78 & $0.16^{* *}$ & 2.40 & $0.15^{* *}$ & 2.37 & $0.21 * * *$ & 3.13 \\
\hline Law and Order & -0.10 & -0.85 & 0.02 & 0.50 & 0.02 & 0.53 & 0.02 & 0.30 \\
\hline Bureaucratic Quality & -0.17 & -1.12 & -0.07 & -0.69 & -0.07 & -0.79 & -0.16 & -1.63 \\
\hline Corruption Absent & 0.06 & 0.38 & 0.04 & 0.32 & 0.08 & 0.78 & 0.16 & 1.40 \\
\hline Democratic Accountability & 0.01 & 0.14 & 0.04 & 0.73 & 0.09 & 1.47 & 0.08 & 1.17 \\
\hline Military Absent in Politics & 0.03 & 0.32 & 0.01 & 0.16 & 0.03 & 0.46 & 0.03 & 0.59 \\
\hline Ethnic Tension Absent & 0.05 & 0.62 & 0.04 & 1.04 & 0.07 & 1.47 & 0.06 & 1.26 \\
\hline Religious Tensions Absent & 0.18 & 1.54 & $0.07 * *$ & 2.35 & $0.08 * *$ & 2.53 & $0.09 * *$ & 2.47 \\
\hline Socioecon. Stress Absent & -0.28 & -1.55 & 0.02 & 0.28 & 0.09 & 0.84 & 0.10 & 1.00 \\
\hline Internal Conflict Absent & 0.00 & -0.03 & -0.03 & -0.50 & -0.1 & -1.41 & -0.02 & -0.31 \\
\hline External Conflict Absent & 0.15 & 1.33 & 0.05 & 0.77 & 0.01 & 0.11 & -0.04 & -0.59 \\
\hline Government Stability & 0.09 & 0.64 & $0.15^{*}$ & 1.84 & $0.15^{*}$ & 1.86 & 0.12 & 1.56 \\
\hline Gov Expenditure & -0.01 & -0.34 & -0.02 & -0.70 & -0.010 & -0.24 & 0.00 & -0.13 \\
\hline Log Pop & & & & & & & -0.05 & -0.51 \\
\hline Log GNI & & & & & & & $0.61^{* * *}$ & 3.31 \\
\hline Log GNI per capita & $0.68^{* * *}$ & 3.71 & $0.69 * * *$ & 5.29 & $0.55^{* * *}$ & 3.04 & & \\
\hline Log GNI Growth & $0.25 * * *$ & 3.48 & $0.15^{* * *}$ & 3.07 & & & & \\
\hline Log Trade & $0.84 * * *$ & 2.66 & $0.52 * * *$ & 2.64 & $0.65^{* * *}$ & 3.15 & $0.42 * *$ & 2.04 \\
\hline Log Inflation & -0.01 & -0.20 & 0.04 & 0.56 & 0.01 & 0.16 & 0.06 & 0.73 \\
\hline Constant & $-7.25^{* * * *}$ & -3.10 & $-5.93 * * *$ & -5.12 & $-5.57 * * *$ & -4.65 & $-5.04 * *$ & -2.54 \\
\hline \# Observations & 468 & & 534 & & 604 & & 531 & \\
\hline \# Countries & 77 & & 81 & & 83 & & 82 & \\
\hline
\end{tabular}

1 The t-statistics are computed using clustered standard errors (clustering by country). The asterisks “***," “**," and "*” denote statistical significance at the $1 \%, 5 \%$ and $10 \%$ levels, respectively.

2 Model A dependent variable is the log (IHS) of net FDI flows per capita. Model B is identical to Model A, but with gross inflows rather than net flows as the dependent variable. In Model $\mathrm{C}$, the dependent variable is also the $\log$ (IHS) of gross FDI inflows per capita, but controlling for only one national income variable. Model D is identical to Model C, but relaxes the restriction on the estimated national income and population relationships by separating log GNI per capita into its component terms. All models include country and time effects. 


\section{Online Appendix 14: Random Effects Estimates of Expected Approximate log FDI as a Function of Five Semi-Aggregated Composite Political Risk Measures Based on the Four Taxonomies in Table 1}

\begin{tabular}{|c|c|c|c|c|c|c|c|c|}
\hline \multirow[b]{2}{*}{ VARIABLES } & \multicolumn{2}{|c|}{ Taxonomy 1} & \multicolumn{2}{|c|}{ Taxonomy 2} & \multicolumn{2}{|c|}{ Taxonomy 3} & \multicolumn{2}{|c|}{ Taxonomy 4} \\
\hline & coef & tstat & coef & tstat & coef & tstat & coef & tstat \\
\hline Exprop. Risk Absent Comp. & $0.18 * *$ & 2.41 & $0.19 * * *$ & 3.07 & $0.23 * * *$ & 2.78 & $0.34 * * *$ & 2.96 \\
\hline Gov Efficiency Comp. & 0.02 & 0.30 & 0.06 & 0.75 & 0.04 & 0.45 & 0.02 & 0.28 \\
\hline Gov Stability Comp. & $0.27 * *$ & 2.26 & $0.24 * *$ & 2.12 & $0.23 * *$ & 2.48 & 0.11 & 1.11 \\
\hline Political Account. Comp. & $0.24 * *$ & 2.39 & $0.23 * *$ & 2.30 & 0.09 & 1.52 & $0.23 * *$ & 2.43 \\
\hline Conflict Absent Comp. & -0.07 & -0.60 & -0.05 & -0.42 & -0.06 & -0.71 & -0.08 & -0.64 \\
\hline Gov Expenditure & -0.01 & -0.24 & 0.00 & -0.13 & -0.01 & -0.25 & -0.01 & -0.24 \\
\hline Log Pop & -0.11 & -1.53 & -0.09 & -1.25 & -0.1 & -1.27 & -0.11 & -1.47 \\
\hline $\log$ GNI & $0.52 * * *$ & 2.77 & $0.50 * * *$ & 2.69 & $0.64 * * *$ & 3.94 & $0.54 * * *$ & 2.84 \\
\hline Log Trade & 0.32 & 1.54 & 0.33 & 1.57 & 0.33 & 1.61 & 0.33 & 1.54 \\
\hline Log Inflation & 0.07 & 0.95 & 0.08 & 1.02 & 0.06 & 0.76 & 0.07 & 0.89 \\
\hline Constant & -2.52 & -1.60 & $-3.05 * *$ & -1.97 & $-3.19 *$ & -1.90 & -2.53 & -1.50 \\
\hline \#Observations & 531 & & 531 & & 531 & & 531 & \\
\hline \#Countries & 82 & & 82 & & 82 & & 82 & \\
\hline \multicolumn{9}{|c|}{$\begin{array}{l}1 \text { The t-statistics are computed using clustered standard errors (clustering by country). The asterisks “***," “**," } \\
\text { and "**" denote statistical significance at the } 1 \%, 5 \% \text { and } 10 \% \text { levels, respectively. The four taxonomies apply } \\
\text { different definitions for the five semi-aggregated composite political risk variables as summarized in Table } 1 \text {. } \\
2 \text { Reported estimates are based on the Model D specification, with the log (IHS) of gross FDI inflows as the } \\
\text { dependent variable and unrestricted coefficient estimates for the national income and population variables. All } \\
\text { models include country and time effects. }\end{array}$} \\
\hline
\end{tabular}

